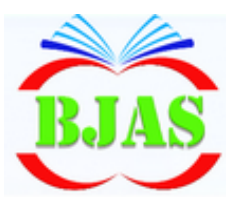

Available online at: http//bjas.bajas.edu.iq

College of Agriculture, University of Basrah

DOi:10.21276/basjas

ISSN 1814 - 5868 Basrah J. Agric. Sci., 32(Spec Issue): 98-123, 2019

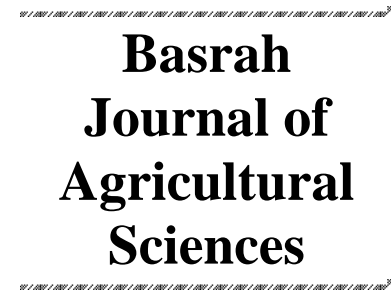

E-ISSN: 2520-0860

\title{
Fish Assemblage of Ktiban creek the upper Reach of Shatt Al-Arab River
}

\section{Kadhim H. Hasan* \& Amjad K. Resen}

Department of Fisheries and Marine Resources, College of Agriculture, University of Basrah, Basrah, Iraq

*Corresponding author e-mail: kazim.alkafaji@jibal-it.net

Received 19 April 2019; Accepted 11 June 2019; Available online 1 September 2019

\begin{abstract}
The study was conducted at the Shatt Al-Arab River at Ktiban creek in three stations during the period from October 2017 to September 2018. The first station was in the Shatt Al-Arab near Al- Hartha power Station, the second and third stations were in the Ktiban creek. Samples were collected once a monthly. A total of 5106 fish were collected from the study, period included 24 species belong to 12 families, and consisted of eight marine species and 16 freshwater species (nine native and seven exotic species). Physical and chemical characteristics were measured during sampling period. water temperature, dissolved oxygen, $\mathrm{pH}$, light penetration, salinity, current flow, total dissolve solid (TDS), nitrate, nitrite and phosphates The range of parameters in the Shatt Al-Arab were within their normal levels except salinity values and TDS (8.7 PSU and $8210 \mathrm{mg} / 1$ respectively). The values of the diversity index $(\mathrm{H})$ were calculated in the study stations between $1.06-1.87$ and evenness index (j) ranged from $0.42-0.83$ and richness index(D) between $1.00-2.62$.
\end{abstract}

Keywords: Fertility traits, Polymorphism, sheep, TGF-B gene.

\section{Introduction}

Shatt Al-Arab is one of the main rivers in Iraq. Because it is economically and socially important so It is the main source of water surface In the province of Basra. Shatt alArab has been still used for purposes irrigation, aquaculture fisheries, river transport and industrial (Moyel, 2014). Aquatic ecosystems and other fish and life communities are directly and indirectly affected by environmental factors (Gomes $e t$ al., 2001). Temperature, salinity, $\mathrm{pH}$ and nutrient concentration affect the structure of fish communities and lead to increase bioactivity of fish interactions. The importance of these factors have led to differences in control and conservation of these communities (Ibarra et al., 2005). Water temperature is one of the most important factors affecting the structure of the fish community and the abundance of species (Clark, 2003). The Salinity is also great importance in the aquatic environment and a determinant factor of fish growth (O'Neill et al., 2011; Pérez-Robles et al., 2012; Fazio et $a l ., 2013)$. The transparency of light through the water column is an valuable 
environmental factor influencing the activity and structure of fish communities and their relationship to other food and life (Mrosso et al., 2004). The presence of nutrients in the aquatic environment is essential for sustainability and productivity, which is the primary food pyramid aquatic base including fish (Wetzel, 2001).

The study of freshwater fish communities is an important factor in understanding the abundance and diversity of fish in the water surface by using environmental indces including the Richness, the Diversity, and the Evidence Indices (Pihl and Wennhage, 2002). Several local studies have been conducted to describe the nature of fish assemblages omitted in many water bodies in Iraq, especially in the Shatt al-Arab (Hussain et al., 1997; Jassim, 2003; Younis, 2005; Mahmood et al. 2008; Lazem, 2009; Mohamed, 2010; Mohamed et al. 2012; Lazem, 2014; Abdullah, 2015; Al-Okailee et al., 2016; Mohamed et al., 2017; Mohamed \& Abood, 2017b).

Due to the lack of environmental and fish ecological studies on the ktiban creek near the conveyor canal which is identified by water resources as the end of the saline tide, the present study aims to give an example for describing the nature of the fish community ,dominant and abundance of species in the Shatt al-Arab and the Ktiban creek through the use of biological indices. as well as, study of the environmental changes in the region to identify their impact on the presence of species.

\section{Materials \& Methods}

The current study was conducted on the creek of ktiban, Northeastern of Basrah Province, one of the branches of the Shatt Al-Arab river. The length of the river is about. $4.5 \mathrm{~km}$.
It is about $25 \mathrm{~m}$ wide and the depth is 3-3.5 m. The study area is affected. semi-diurnal tide. The region is also characterized by various intensities of aquatic plants, Ceratophyllum demersum that was as adense strap during the study period and Phragmites australis, Typha australis, Vallisneria spiralis Schoenoplectus litoralis, which were intensity fluctuates with the seasons and classified according to Al-Abbawy \& Al-Mayah (2010). Three sampling stations were selected as clarified in fig. (1)

The first station is located on the other side opposite to the Hartha station in the Shatt alArab and close to the branch of the Ktiban creek within the site of $30^{\circ} 41^{\prime} 30.6^{\prime \prime}$ North and $47^{\circ} 45^{\prime} 23.36^{\prime \prime}$ East, the width of this area $21.5 \mathrm{~m}$ and the depth of water through the lowest tide between 3- $4.5 \mathrm{~m}$. The second station is located near the bridge of the yellow ktiban creek after the regulator and is located $1 \mathrm{~km}$ away from the first station at $30^{\circ} 41^{\prime} 43.39^{\prime \prime} \mathrm{N}$ and $47^{\circ} 45^{\prime} 37.6^{\prime \prime} \mathrm{E}$, known as the Biban region, the width of the river in this area reaches $25 \mathrm{~m}$ and the depth of the water is 1.5 to $2 \mathrm{~m}$. The third station is located in the ktiban river at site $30^{\circ} 42^{\prime} 38.82^{\prime \prime}$ North and $47^{\circ} 46^{\prime} 55.46^{\prime \prime}$ East and known as the area of Ruwab and away from the second station with $3.220 \mathrm{~km}$, the width of this area $20 \mathrm{~m}$ and the depth of water $2-2.5 \mathrm{~m}$.

Water and fish samples were collected from the stud stations from the period of October 2017 to September 2018, with one sample per month during ebb tide time for some environmental factors, including water temperature, salinity, dissolved oxygen, light transparency, active $\mathrm{NO}_{3}$, and active phosphate. Three fishing methods were adopted Drift gill net with a length of $120 \mathrm{~m}$ and a height of $4 \mathrm{~m}$ and mesh size $16 \times 16$ $\mathrm{mm}$ time was 30 minutes process was 
Hasan \& Resen / Basrah J. Agric. Sci., 32 (Special Issue): 98-123, 2019

achieved. Cast net with diameter of $9 \mathrm{~m}$ and mesh size hole $22 \times 22 \mathrm{~mm}$. Electro-fishing with power 500 volts with distance effect of 2 $\mathrm{m}^{2}$ in low-density near dense plants. The fishes were kept in icebox until reached to the laboratory and the fish were classified according to Carpenter et al. (1997) and Coad (2017).

The number of species were recorded and the weight and total length were measured.
Ecological indices were calculated that include Diversity index according to Shannon and Winner (1949), Richness index according to Margalefe (1968) and Evenness index according to Pielou (1977). Canonical Correspondence Analysis (CCA) using the Canoca program version 4.5 to assess the relationships between different environmental factors and fish communities. The Statistical Program (SPSS) was used for data analysis at significance 0.05 .

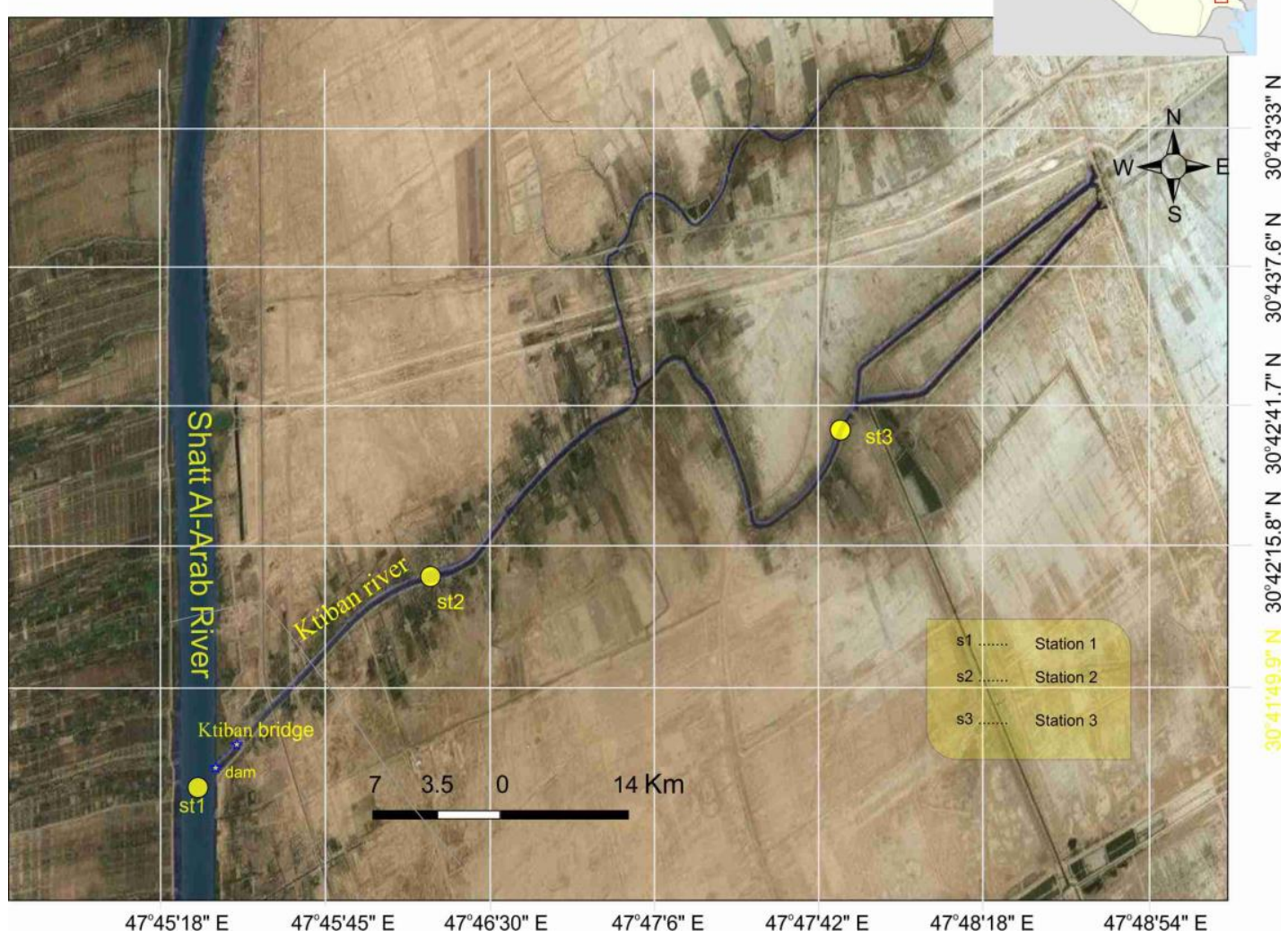

Fig. (1) Map showing the study sites on the Ktiban river. 


\section{Results}

\section{Water temperature}

Fig. (2) exhibited the monthly changes of the water temperature in the studied stations. The lowest temperature degrees were $18^{\circ} \mathrm{C}, 19^{\circ} \mathrm{C}$ and $19{ }^{\circ} \mathrm{C}$ in January 2018 at the first, second and third stations respectively. whereas water temperature increased gradually to reach highest of $34{ }^{\circ} \mathrm{C}, 35^{\circ} \mathrm{C}$ and $36^{\circ} \mathrm{C}$ during July 2018 for the first, second and third stations, respectively.

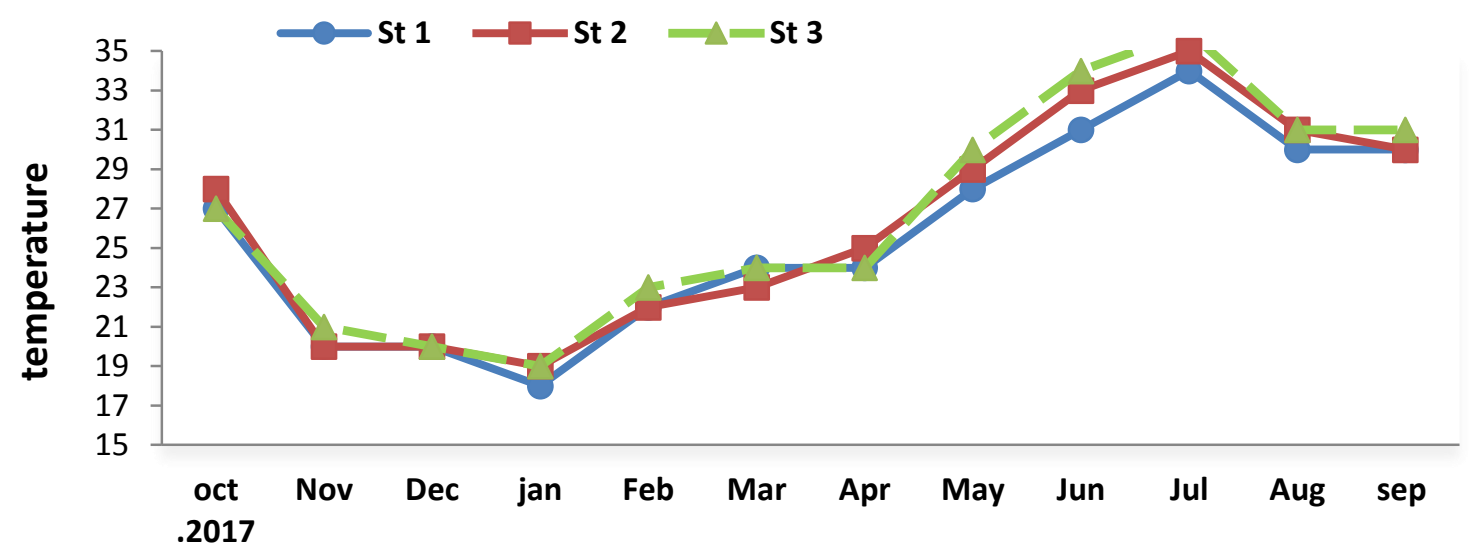

Fig. (2): Local monthly changes in water temperature values of selected stations during the period from Oct 2017 to Nov. 2018.

\section{Salinity}

Fig. (3) indicated the monthly changes in salinity in Ktiban creek during the study period. The lowest values of salinity were recorded in January (2.2, 2 and 2) PSU for the first, second and third stations respectively, while the highest salinity values were recorded in September (8.7, 8 and 7.2) PSU for the first, second and third stations respectively.

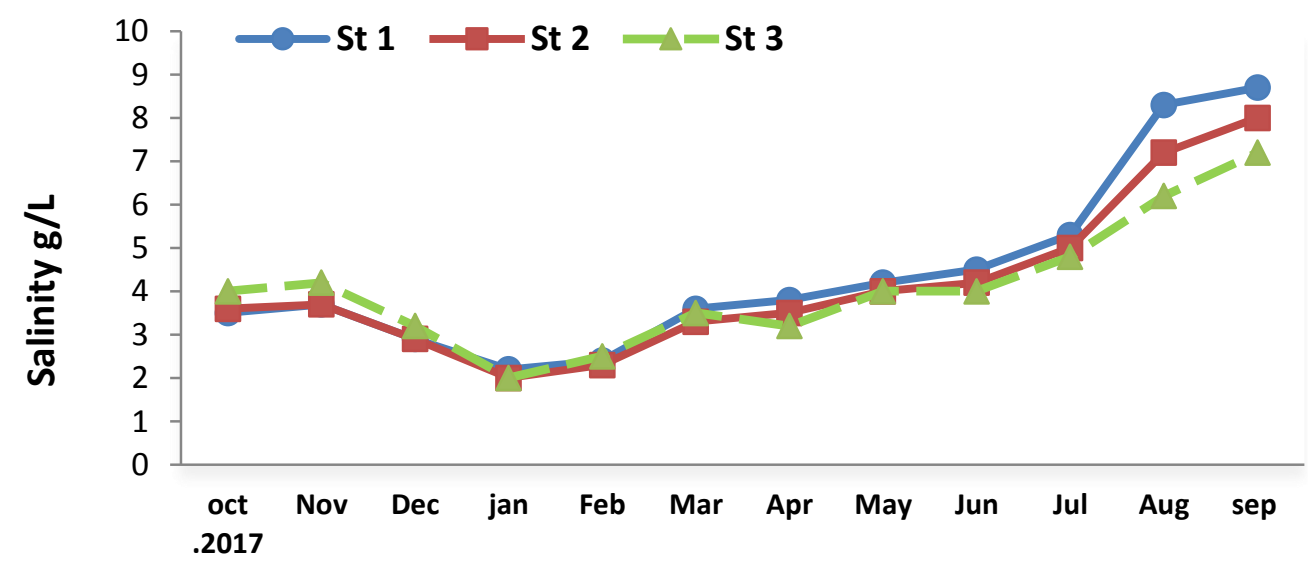

Fig. (3): Local monthly changes in salinity of selected stations during the period from Oct 2017 to Nov. 2018. 


\section{Dissolved Oxygen}

Fig. (4) revealed the monthly changes in dissolved oxygen of the study stations. The lowest oxygen values was recorded in July (4.6, 4.3 and 4.1) $\mathrm{mg}^{-1}$ in the first, second and third stations respectively. The highest oxygen values were $12 \mathrm{mg} . \mathrm{l}^{-1}$ in December for the first station and $11.8 \mathrm{mg} . \mathrm{l}^{-1}$ in February for the second station and $11.5 \mathrm{mg} . \mathrm{l}^{-}$ ${ }^{1}$ in January 2018 for the third station.

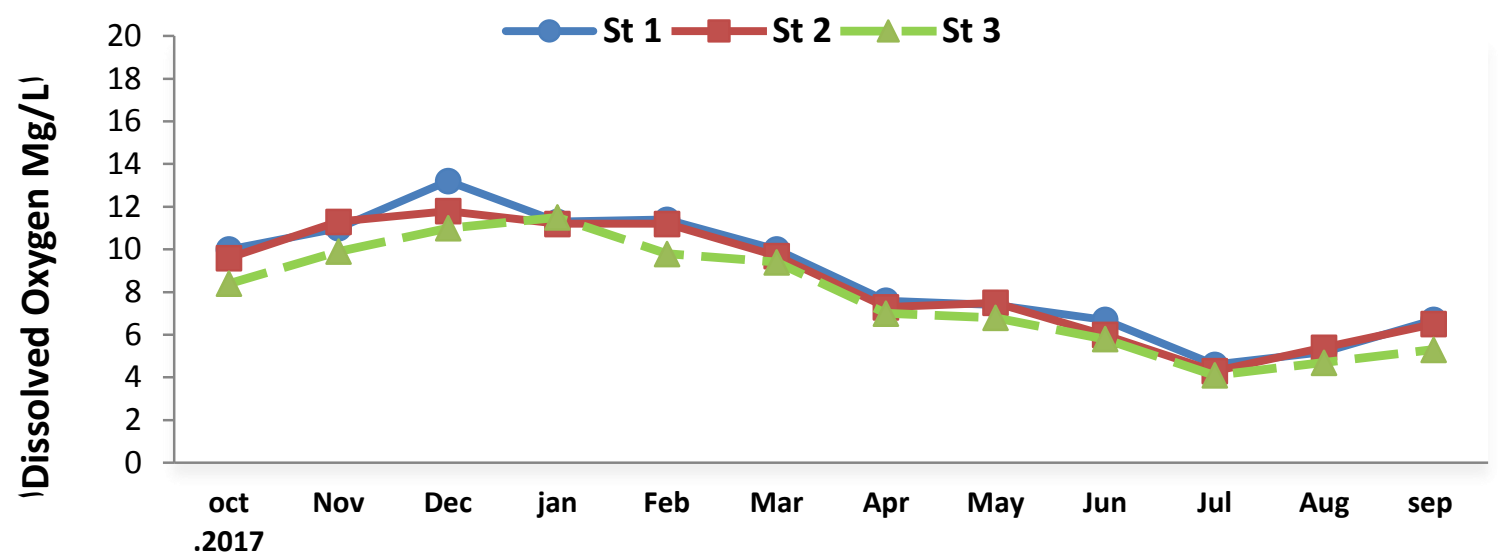

Fig. (4) local monthly changes in dissolved oxygen values during the period from Oct 2017 to Nov. 2018.

\section{Light penetration}

Fig. (5) presented the monthly changes in light penetration values during the water column at the studied stations. The lowest permeability of the light were $(33 \mathrm{~cm}, 31$ and 38) $\mathrm{cm}$ in May for the first, second and third stations respectively, while the highest values were $(60,54$, and 55$) \mathrm{cm}$ for the first station, second and third stations, respectively.

\section{Nitrate (NO3)}

Fig. (6) indicated the monthly changes in the nitrate values for the studied stations, which recorded a significant increase during the study period. The lowest values were 44.35,
$40.67 \mu \mathrm{g}-\mathrm{N}-\mathrm{No}_{3} . \mathrm{I}^{-1}$ in September 2018 at the first and second stations respectively, and $43.34 \mu \mathrm{g}-\mathrm{N}-\mathrm{No}_{3} . \mathrm{l}^{-1}$ in August for the third station, while the highest values were 97.11, 96.82 and $95.87 \mu \mathrm{g}-\mathrm{N}-\mathrm{No}_{3} \mathrm{l}^{-1}$ in June and September respectively.

\section{Reactive Phosphate}

Fig. (7) exhibited the monthly changes in phosphate concentration values during the studied stations, with the lowest values of $0.063,0.114$ and $0.105 \mu \mathrm{g}$. $\mathrm{P}_{-}-\mathrm{PO}_{4} . \mathrm{I}^{-1}$ in June, July and August of the first, second and third stations respectively, while the highest values were $(0.438,0.495$.and 0.383$) \mu \mathrm{g}$. $\mathrm{P}-\mathrm{PO}_{4} . \mathrm{l}^{-1}$ in November 2017 for the first and second third stations, respectively. 
Hasan \& Resen / Basrah J. Agric. Sci., 32 (Special Issue): 98-123, 2019

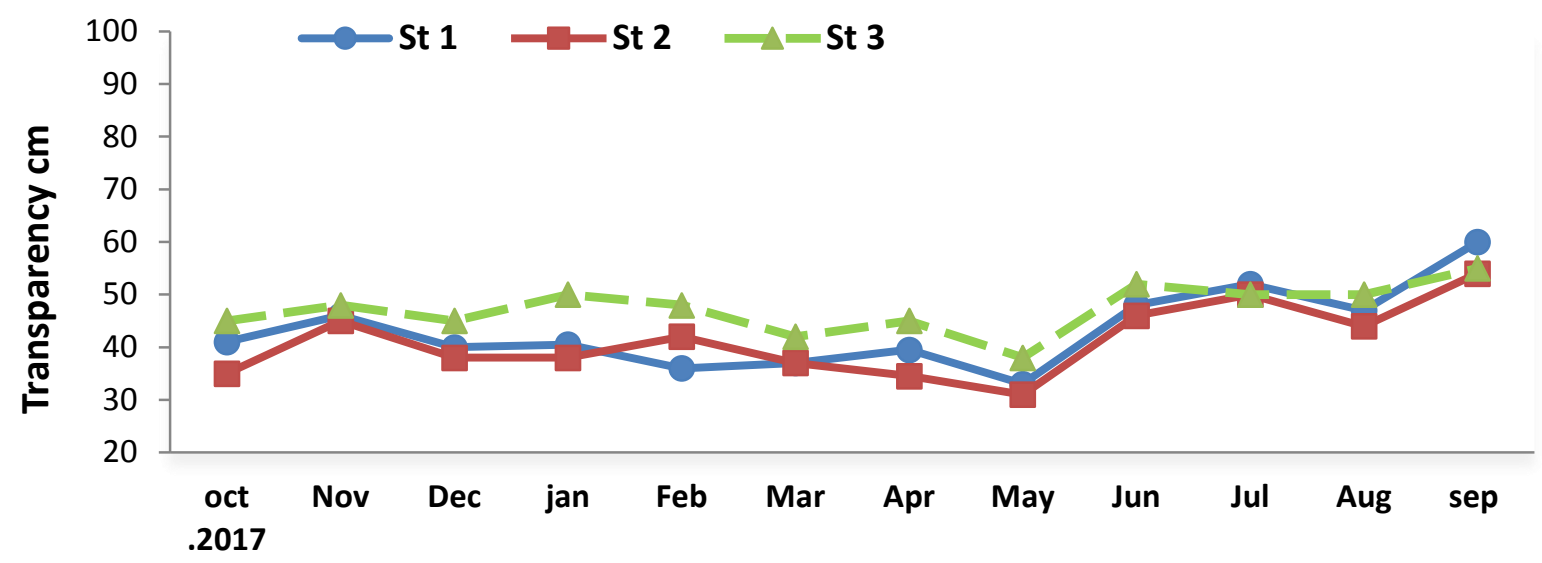

Fig. (5): Local monthly changes in light permeability values of selected stations during the period from Oct 2017 to Nov. 2018.

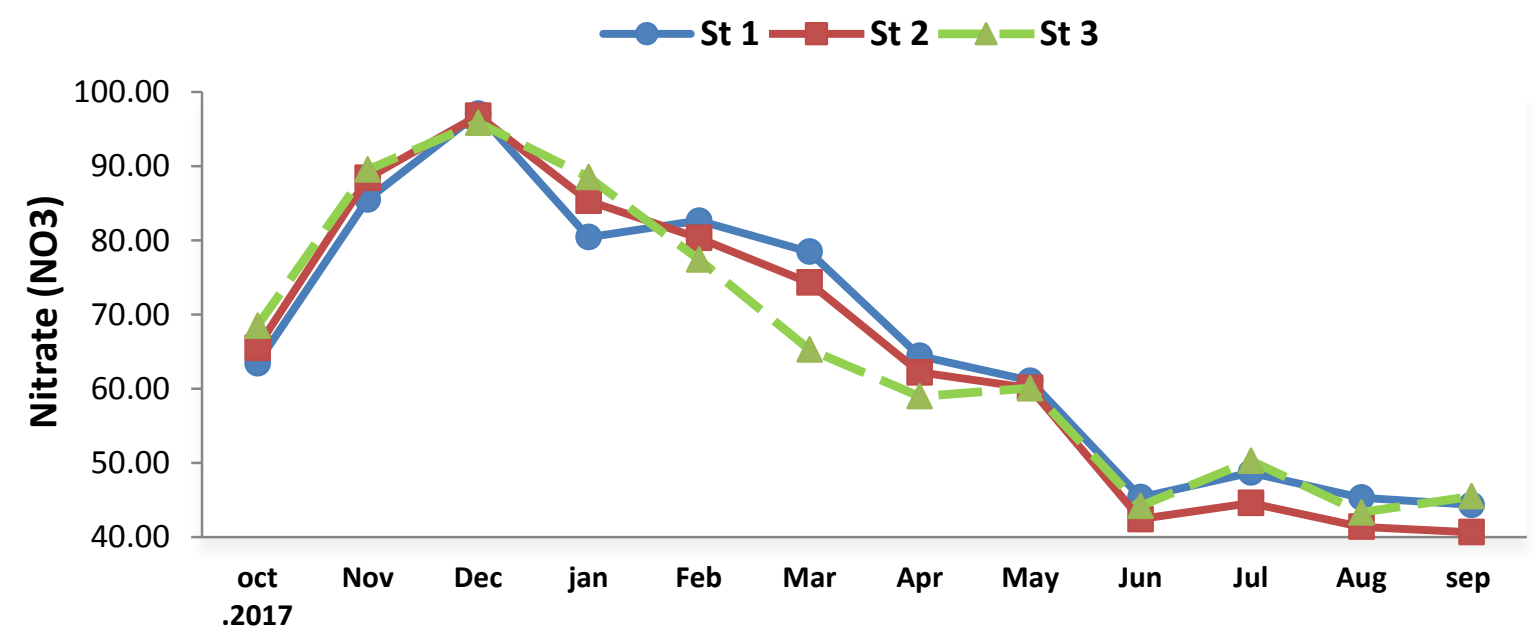

Fig. (6): Monthly changes in nitrate concentration values for selected stations during the period from Oct 2017 to Nov. 2018.

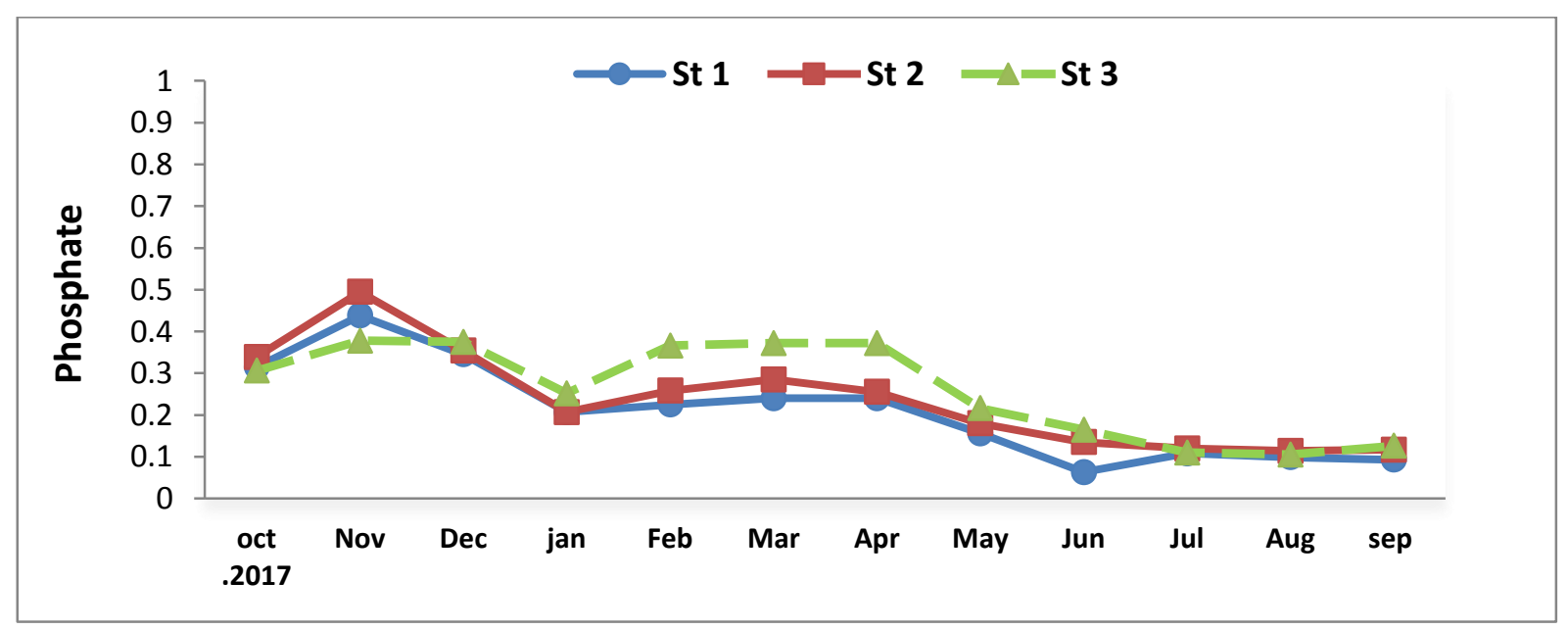

Fig. (7) Monthly changes in phosphate concentration values of selected stations during the period from Oct 2017 to Nov. 2018. 


\section{Fish Assemblage}

A total of 5105 fish individual were collected, including 24 species from studied stations belong to 21 genera and 12 families all from the Osteichthyes, representing eight marine species and 16 freshwater species (Nine native species and seven alien species) as shown in table (1).

Fig. (8) revealed monthly changes in the number of fish species in the study area, with a total of 24 species in the first station. The number of species that recorded ranged from six species in December to 14 species in February and March for first station, 20 species in the second station and varied between six species in December and 14 species in May. While 14 species were recorded in the third station and varied between six species in February and March and nine species in October 2017 and May 2018.

Fig. (9) indicated the monthly changes in the number of fish individual of the study area. The total numbers reached 2314 fish in the first station ranging between 115 individuals in August 2018 and 317 individuals in May 2018. The total number of individuals in the second station was 1434 and varied between 72 individuals in January 2018 to 205 individuals in October 2017. The total number of individuals in the third station was 1357 individuals and varied between 59 individuals in July 2018 and 240 individuals in November 2017.

Fig. (10) exhibited the monthly changes in fish weight in the study area. The total weight of individuals was $5640.55 \mathrm{~g}$ for the first station. The monthly weights ranged from $191.33 \mathrm{~g}$ in and $981.68 \mathrm{~kg}$ in August and January 2017 respectively. In the second station the total weight was $4279.74 \mathrm{~g}$ and the weight fluctuated from $201.40 \mathrm{~g}$ in June to $533.91 \mathrm{~g}$ in February 2018. The total weight of individuals was $5209.91 \mathrm{~g}$ for the third station and the monthly weights ranged between $241.32 \mathrm{~g}$ in June and $960.77 \mathrm{~g}$ in February 2018. 
Hasan \& Resen / Basrah J. Agric. Sci., 32 (Special Issue): 98-123, 2019

Table (1): Fish families, species and habitat in the northern part of the Shatt Al-Arab in the Ktiban creek for the period from October 2017 to September 2018.

\begin{tabular}{|c|c|c|c|}
\hline NO. & Fish species & Family & Habitat \\
\hline 1 & Acanthobrama marmid & \multirow{8}{*}{ Cyprinidae } & $\mathrm{F}$ \\
\hline 2 & Alburnus sellal & & $\mathrm{F}$ \\
\hline 3 & Carasobarbus luteus & & $\mathrm{F}$ \\
\hline 4 & Carassius auratus & & A \\
\hline 5 & Garra rufa & & $\mathrm{F}$ \\
\hline 6 & Hemiculter leucisculus & & A \\
\hline 7 & Cyprinus carpio & & A \\
\hline 8 & Leuciscus vorax & & $\mathrm{F}$ \\
\hline 9 & Thryssa hamiltonii & \multirow{2}{*}{ Engraulidae } & M \\
\hline 10 & Thryssa whiteheadi & & M \\
\hline 11 & Tenualosa ilisha & Clupeidae & M \\
\hline 12 & Mystus pelusius & Bagridae & $\mathrm{F}$ \\
\hline 13 & Silurus triostegus & Siluridae & $\mathrm{F}$ \\
\hline 14 & Poecilia latipinna & Poeciliidae & A \\
\hline 15 & Mastacembelus mastacembelus & Mastacembelidae & $\mathrm{F}$ \\
\hline 16 & Coptodon zillii & \multirow{3}{*}{ Cichlidae } & A \\
\hline 17 & Oreochromis aureus & & A \\
\hline 18 & Oreochromis niloticus & & A \\
\hline 19 & Acanthopagrus arabicus & Sparidae & M \\
\hline 20 & Bathygobius fuscus & \multirow{2}{*}{ Gobiidae } & M \\
\hline 21 & Boleophthalmus dussumieri & & M \\
\hline 22 & Photopectoralis bindus & Leiognathidae & M \\
\hline 23 & Planiliza abu & \multirow[t]{2}{*}{ Mugilidae } & $\mathrm{F}$ \\
\hline 24 & Planiliza subviridis & & M \\
\hline
\end{tabular}

*A-Alien species, F-Freshwater species \& M-Marine species). 
QSt 1 QSt $2 \quad \square$ St 3

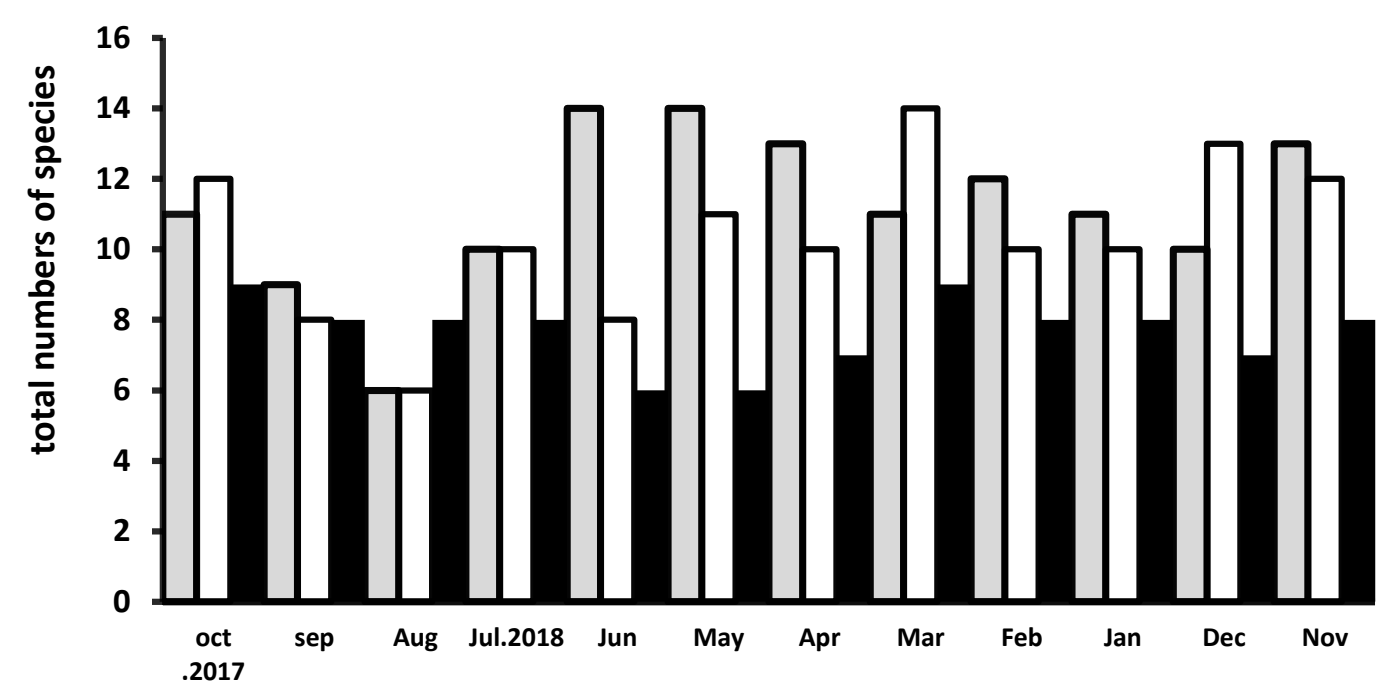

Fig. (8) Monthly changes in the numbers of fish species in the ktiban creek during the period from Oct 2017 to Nov. 2018.

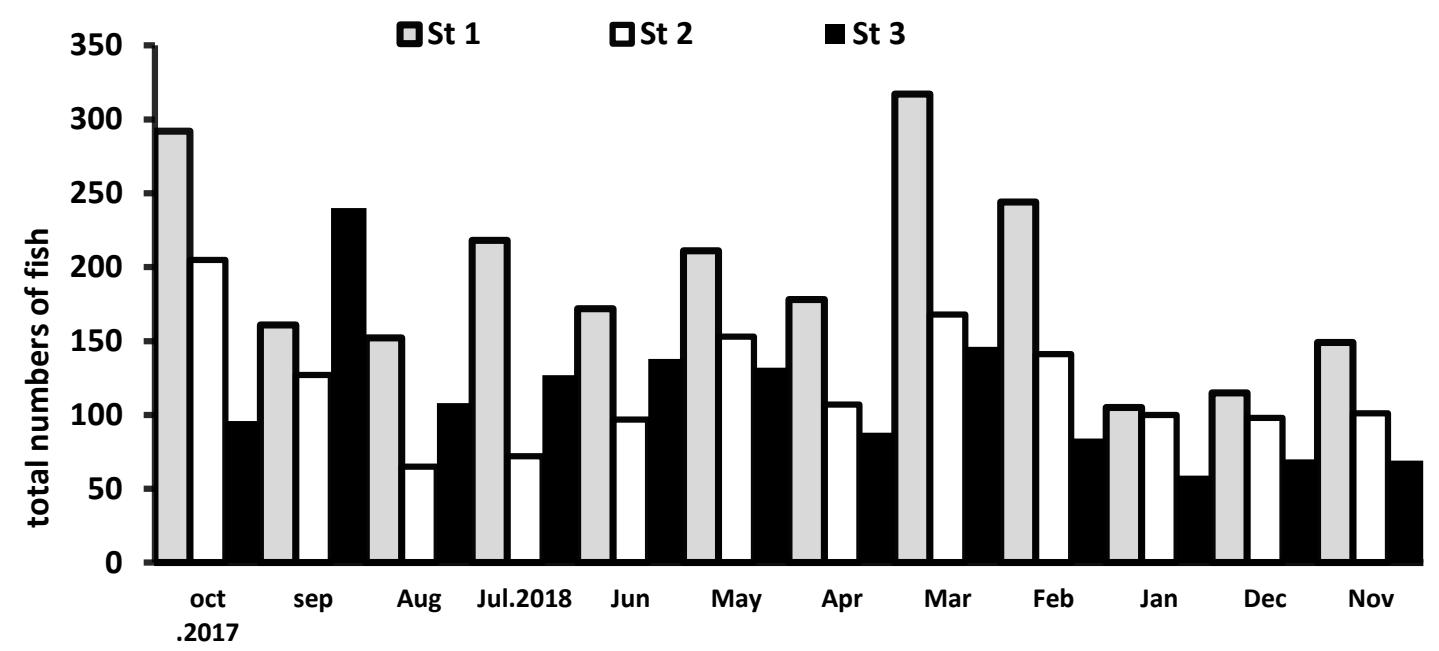

Fig. (9): Monthly changes in the total numbers of individuals in the the ktiban creek during the period from Oct 2017 to Nov. 2018.

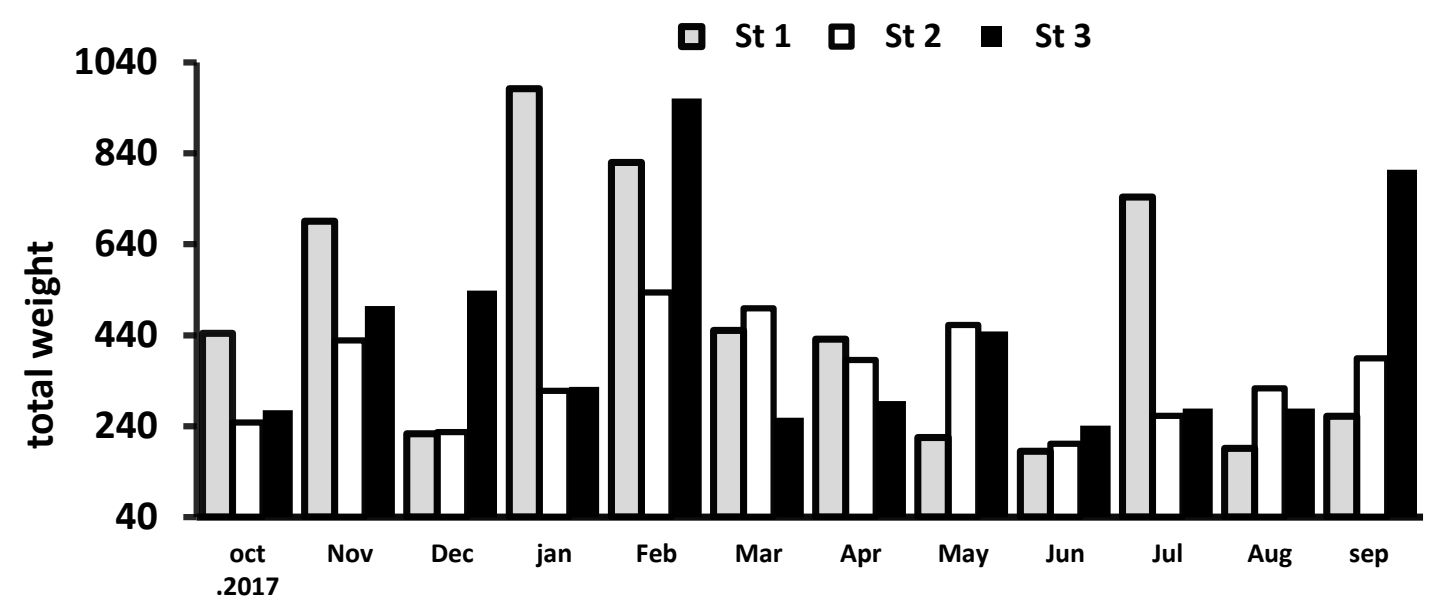

Fig (10) Monthly changes in the total weight of individuals in the study stations. 
Fig. (11) displayed the monthly changes in the number of, native, exotic and marine species in the studied stations. The number of native, exotic and marine species in the first station was nine, seven and eight species respectively were recorded. The number of native, exotic and marine species in the second station was seven, seven and six species respectively were recorded. The number of native, exotic and marine species in the third station was five, six and three species respectively were recorded.

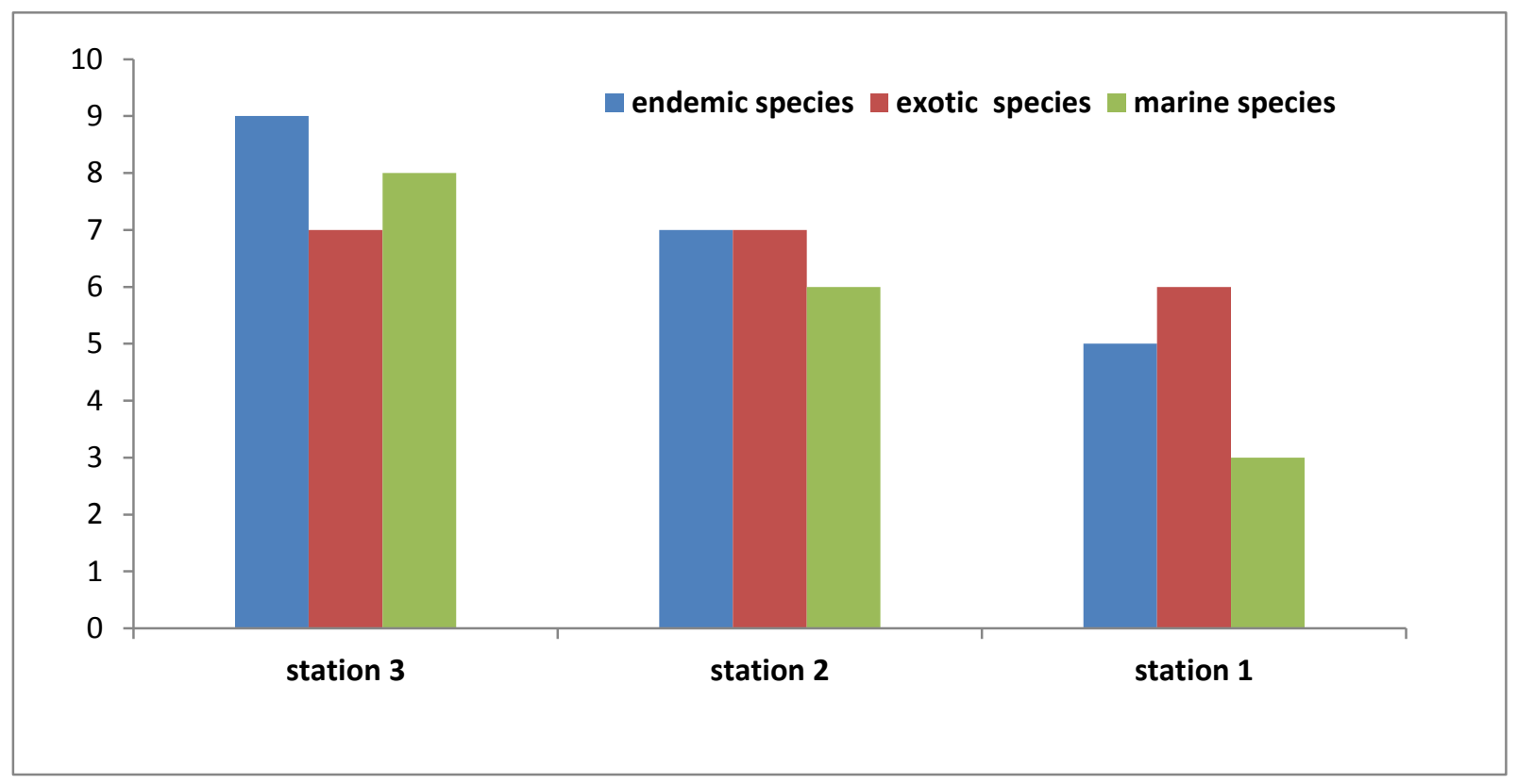

Fig. (11): Monthly changes in the number of Native, exotic and marine species in the studied stations at ktiban creek during the period from Oct 2017 to Nov. 2018.

\section{Relative abundance}

Table (2) presented the monthly changes in the numerical and relative abundance of the fishes in the first station during the study period. The number of dominant fish species varied, with $82.88 \%$ of the total number of fishes. However the number of the Nile tilapia (O. niloticus) has taken place the first, with 605 individuals and $26.12 \%$ and the relative duration ranged between $4.7 \%$ in September 2018 and $45.96 \%$ in November 2017. In second level Prussian carp C. auratus with a numerical abundance of 464 and a the relative abuncance of $20.3 \%$ ranging $0.47 \%$ in March and $59.7 \%$ in September The redbelly tilapia C. zillii was the third level with a numerical and relative abundance of 304 and $13.13 \%$ respectively and ranged from $0.7 \%$ in September 2018 to $39.47 \%$ in December 2017. The fourth level with blue tilapia $O$. aureus and with 285 and $31.12 \%$ of numerical and relative abundance repectively and ranging between 1.3\% in September 2018 and $24.34 \%$ in December 2017. The swordtail molly $P$. latipinna was fifth in level with numerical and relative abundance 260 and $11.23 \%$ repectively, ranging between $1.32 \%$ in December 2017 and 25.59\% in March 2018 during the study period.

Table (3) exhibited the monthly changes in the numerical and relative abundance in the second station during collection period. The number of four dominance fish species varied, with $75.17 \%$ of the total number of fish. 
Hasan \& Resen / Basrah J. Agric. Sci., 32 (Special Issue): 98-123, 2019

Table (2): The monthly changes in the numerical and relative abundance of the first station during the study.

\begin{tabular}{|c|c|c|c|c|c|c|c|c|c|c|c|c|c|c|c|c|c|c|c|c|c|c|c|c|c|c|}
\hline Snecies & Oct-17 & & Nov & & Dec & & jan & & Feb & & Mar & & Apr & & May & & Jun & & $\mathrm{Jul}$ & & Aug & & Sep & & Total & $0 \%$ \\
\hline Species & Num & $9 \%$ & Num & $9 \%$ & Num & 96 & Num & 96 & Num & $9 \%$ & Num & $9 \%$ & Num & $9 \%$ & Num & $9 \%$ & Num & $9 \%$ & Num & $9 \%$ & Num & $9 \%$ & Num & $9 \%$ & Num & \\
\hline O. niloticus & 71 & 24.32 & 74 & 45.96 & 44 & 29 & 78 & 35.78 & 40 & 23.26 & 60 & 28.44 & 51 & 28.7 & 111 & 35 & 55 & 22.45 & 8 & 7.62 & 6 & 5.22 & 7 & 4.7 & 605 & 26.12 \\
\hline C. auratus & 47 & 16.1 & 8 & 4.97 & 6 & 4 & 11 & 5.05 & 31 & 18.02 & 1 & 0.47 & 13 & 7.3 & 76 & 24 & 60 & 24.49 & 56 & 53.33 & 66 & 57.39 & 89 & 59.7 & 464 & 20.03 \\
\hline C. zillii & 26 & 8.9 & 24 & 14.91 & 60 & 39 & 51 & 23.39 & 30 & 17.44 & 34 & 16.11 & 24 & 13.5 & 8 & 2.5 & 46 & 18.78 & & & & & 1 & 0.7 & 304 & 13.13 \\
\hline O. aureus & 67 & 22.95 & 31 & 19.25 & 37 & 24 & 52 & 23.85 & 21 & 12.21 & 12 & 5.69 & 12 & 6.74 & 30 & 9.5 & 17 & 6.94 & 4 & 3.81 & & & 2 & 1.3 & 285 & 12.31 \\
\hline P. latipinna & & & & & 2 & 1.3 & 20 & 9.17 & 6 & 3.49 & 54 & 25.59 & 36 & 20.2 & 72 & 22.7 & 37 & 15.1 & 8 & 7.62 & 17 & 14.78 & 8 & 5.4 & 260 & 11.23 \\
\hline P. $a b u$ & 48 & 16.44 & 15 & 9.32 & 3 & 2 & 2 & 0.92 & 8 & 4.65 & 1 & 0.47 & 2 & 1.12 & 4 & 1.3 & 13 & 5.31 & 14 & 13.33 & 12 & 10.43 & 18 & 12.1 & 140 & 6.04 \\
\hline H. leucisculus & 4 & 1.37 & & & & & 1 & 0.46 & 15 & 8.72 & 15 & 7.11 & 13 & 7.3 & 3 & 0.9 & 5 & 2.04 & 4 & 3.81 & 6 & 5.22 & 5 & 3.4 & 71 & 3.07 \\
\hline T. whiteheadi & 20 & 6.85 & 3 & 1.86 & 0 & 0 & & & 4 & 2.33 & 5 & 2.37 & 7 & 3.93 & 4 & 1.3 & 3 & 1.22 & 2 & 1.9 & 1 & 0.87 & 8 & 5.4 & 57 & 2.46 \\
\hline P. subviridis & 1 & 0.34 & 2 & 1.24 & 0 & 0 & & & 1 & 0.58 & 10 & 4.74 & 9 & 5.06 & 2 & 0.6 & & & & & 1 & 0.87 & & 0 & 26 & 1.12 \\
\hline A. sellal & & & & & & & 1 & 0.46 & 9 & 5.23 & & & & & & & & & 2 & 1.9 & & & 3 & 2 & 15 & 0.65 \\
\hline M. pelusius & & & & & & & & & & & 10 & 4.74 & 5 & 2.81 & & & & & & & & & & & 15 & 0.65 \\
\hline A. mamid & & & & & & & & & 4 & 2.33 & 5 & 2.37 & & & & & 2 & 0.82 & 2 & 1.9 & & & & & 13 & 0.56 \\
\hline B. fuscus & & & & & & & & & 1 & 0.58 & & & 2 & 1.12 & 4 & 1.3 & 3 & 1.22 & & & 1 & 0.87 & 2 & 1.3 & 13 & 0.56 \\
\hline T. hamiltonii & 4 & 1.37 & & 0 & & 0 & & & & 0 & 1 & 0.47 & 2 & 1.12 & & 0 & & & & & & & 2 & 1.3 & 9 & 0.39 \\
\hline A. arabicus & & & & & & & & & & & & & & & & & 1 & 0.41 & 4 & 3.81 & 3 & 2.61 & & -1 & 8 & 0.35 \\
\hline L. vorax & 3 & 1.03 & 3 & 1.86 & & & & & & & & & & & & & & & & & & & 1 & 0.7 & 7 & 0.3 \\
\hline C. carpio & & & & & & & & & & & & & & & & & & & & & 2 & 1.74 & 3 & 2 & 5 & 0.22 \\
\hline B. dussumien & & & & & & & & & & & & & & & 3 & 0.9 & 2 & 0.82 & & & & & & & 5 & 0.22 \\
\hline T. ilisha & & & & & & & 1 & 0.46 & & & 2 & 0.95 & 2 & 1.12 & & & & & & & & & & & 5 & 0.22 \\
\hline S. triostegus & & & & & & & 1 & 0.46 & 1 & 0.58 & & & & & & & & & 1 & 0.95 & & & & & 3 & 0.13 \\
\hline C. luteus & & & 1 & 0.62 & & & & & & & & & & & & & & & & & & & & & 1 & 0.04 \\
\hline G. rufa & & & & & & & & & & & 1 & 0.47 & & & & & & & & & & & & & 1 & 0.04 \\
\hline P. bindus & 1 & 0.34 & & & & & & & & & & & & & & & & & & & & & & & 1 & 0.04 \\
\hline M. mastacembelus & & & & & & & & & 1 & 0.58 & & & & & & & & & & & & & & & 1 & 0.04 \\
\hline Number individuals & 292 & & 161 & & 152 & & 218 & & 172 & & 211 & & 178 & & 317 & & 244 & & 105 & & 115 & & 149 & & 2314 & \\
\hline Number species & 11 & & 9 & & 6 & & 10 & & 14 & & 14 & & 13 & & 11 & & 12 & & 11 & & 10 & & 13 & & & \\
\hline
\end{tabular}


Hasan \& Resen / Basrah J. Agric. Sci., 32 (Special Issue): 98-123, 2019

Table (3): The monthly changes in the numerical and relative abundance of the second station during the study.

\begin{tabular}{|c|c|c|c|c|c|c|c|c|c|c|c|c|c|c|c|c|c|c|c|c|c|c|c|c|c|c|}
\hline Species & Oct-17 & & $\mathrm{NOV}$ & & Dec & & jan & & Feb & & Mar & & Apr & & May & & Jun & & Jul & & Aug & & Sep & & Total & $\%$ \\
\hline & Num & $\%$ & Num & $\%$ & Num & $\%$ & Num & $\%$ & Num & $\%$ & Num & $\%$ & Num & $\%$ & Num & $\%$ & Num & $\%$ & Num & $\%$ & Num & $\%$ & Num & $\%$ & Num & \\
\hline 0. niloticus & 66 & 32.2 & 52 & 40.94 & 26 & 40 & 25 & 34.72 & 21 & 21.65 & 45 & 29.4 & 26 & 24.3 & 47 & 28 & 42 & 29.79 & 12 & 12 & 3 & 3.06 & 4 & 4 & 369 & 25.73 \\
\hline 0. aureus & 63 & 30.73 & 24 & 18.9 & 26 & 40 & 12 & 16.67 & 21 & 21.65 & 24 & 15.7 & 25 & 23.36 & 23 & 13.7 & 36 & 25.53 & 10 & 10 & 6 & 6.12 & 4 & 4 & 274 & 19.11 \\
\hline C. auratus & 12 & 5.85 & 6 & 4.72 & 1 & 1.54 & 4 & 5.56 & 31 & 31.96 & 11 & 7.19 & 6 & 5.61 & 4 & 2.4 & 16 & 11.35 & 43 & 43 & 58 & 59.18 & 63 & 62.4 & 255 & 17.78 \\
\hline C. zillii & 18 & 8.78 & 16 & 12.6 & 6 & 9.23 & 10 & 13.89 & 11 & 11.34 & 41 & 26.8 & 24 & 22.43 & 39 & 23.2 & 7 & 4.96 & 7 & 7 & 1 & 1.02 & - & $\cdot$ & 180 & 12.55 \\
\hline T. whiteheadi & 12 & 5.85 & 10 & 7.87 & - & - & - & \begin{tabular}{|l|}
$\cdot$ \\
\end{tabular} & - & \begin{tabular}{|l|}
$\cdot$ \\
\end{tabular} & 16 & 10.5 & 12 & 11.21 & 27 & 16.1 & 16 & 11.35 & 7 & 7 & 4 & 4.08 & 3 & 3 & 107 & 7.46 \\
\hline P. $a b u$ & 4 & 1.95 & 16 & 12.6 & - & - & 1 & 1.39 & - & $\cdot$ & - & $\cdot$ & - & \begin{tabular}{|l|}
- \\
\end{tabular} & 1 & 0.6 & 7 & 4.96 & 11 & 11 & 15 & 15.31 & 12 & 11.9 & 67 & 4.67 \\
\hline H. leucisculus & 17 & 8.29 & - & $\cdot$ & 5 & 7.69 & 7 & 9.72 & 3 & 3.09 & 3 & 1.96 & 5 & 4.67 & 10 & 6 & - & $\cdot$ & - & - & 2 & 2.04 & 5 & 5 & 57 & 3.97 \\
\hline A. sellal & 7 & 3.41 & - & - & - & $\cdot$ & 3 & 4.17 & - & $\cdot$ & 1 & 0.65 & 2 & 1.87 & 1 & 0.6 & 9 & 6.38 & 4 & 4 & - & $\cdot$ & 3 & 3 & 30 & 2.09 \\
\hline C. luteus & 1 & 0.49 & - & - & 1 & 1.54 & 5 & 6.94 & 6 & 6.19 & 3 & 1.96 & 2 & 1.87 & 4 & 2.4 & 3 & 2.13 & - & - & 2 & 2.04 & 2 & 2 & 29 & 2.02 \\
\hline I. hamiltonï & 3 & 1.46 & 1 & 0.79 & - & $\cdot$ & - & $\cdot$ & - & $\cdot$ & 6 & 3.92 & 3 & 2.8 & 8 & 4.8 & 4 & 2.84 & 2 & 2 & - & - & 1 & 1 & 28 & 1.95 \\
\hline S. triostegus & - & $\cdot$ & - & $\cdot$ & - & - & - & - & 3 & 3.09 & - & $\cdot$ & - & - & - & - & - & $\cdot$ & - & $\cdot$ & 2 & 2.04 & 1 & 1 & 6 & 0.42 \\
\hline L. vorax & 1 & 0.49 & 2 & 1.57 & - & - & 1 & 1.39 & - & $\cdot$ & - & - & - & - & - & - & - & - & - & - & 1 & 1.02 & - & - & 5 & 0.35 \\
\hline P. latipinna & - & $\cdot$ & - & $\cdot$ & - & - & 4 & 5.56 & 1 & 1.03 & - & - & - & - & - & - & - & - & - & - & - & $\cdot$ & - & - & 5 & 0.35 \\
\hline T. ilisha & 1 & 0.49 & - & - & - & - & - & $\cdot$ & - & - & 1 & 0.65 & 2 & 1.87 & 1 & 0.6 & - & - & - & - & - & - & - & - & 5 & 0.35 \\
\hline B. dussumien & - & - & - & - & - & - & - & - & - & - & - & $\cdot$ & - & $\cdot$ & - & $\cdot$ & - & - & 2 & 2 & 1 & 1.02 & 1 & 1 & 4 & 0.28 \\
\hline C. carpio & - & - & - & - & - & - & - & - & - & - & - & - & - & - & - & - & - & - & - & - & 1 & 1.02 & 2 & 2 & 3 & 0.21 \\
\hline P. subrividis & - & - & - & - & - & - & - & - & - & - & - & - & - & - & 1 & 0.6 & - & - & - & - & 2 & 2.04 & - & - & 3 & 0.21 \\
\hline A. arabicus & - & - & - & - & - & - & - & - & - & - & - & - & - & - & - & - & 1 & 0.71 & 2 & 2 & - & $\cdot$ & - & - & 3 & 0.21 \\
\hline M. pelusius & - & - & - & - & - & - & - & - & - & - & 2 & 1.31 & - & - & 1 & 0.6 & - & $\cdot$ & - & - & - & - & - & - & 3 & 0.21 \\
\hline M. mastacembelus & - & - & - & - & - & - & - & - & - & - & - & - & - & - & 1 & 0.6 & - & - & - & - & - & - & - & $\cdot$ & 1 & 0.07 \\
\hline Number indiriduals & 205 & - & 127 & - & 65 & - & 72 & - & 97 & - & 153 & - & 107 & - & 168 & - & 141 & - & 100 & - & 98 & - & 101 & - & 1434 & $\cdot$ \\
\hline Number species & 12 & - & 8 & - & 6 & - & 10 & - & 8 & - & 11 & - & 10 & - & 14 & - & 10 & - & 10 & - & 13 & - & 12 & - & - & - \\
\hline
\end{tabular}


The Nile tilapia (O. niloticus) was the first level, with 369 and $25.73 \%$. The relative duration ranged between $3.06 \%$ in September 2018 and 45.94\% in November 2017. Blue tilapia $O$. aureus in the second rank with 274 and $19.11 \%$ in numerical abundance and relative abundance respectively, ranging from 4\% in September 2018 to $30.73 \%$ in October 2017. The third level was $C$. auratus, with a numerical abundance of 255 and relative abundance of $17.78 \%$, ranging between 1.54\% in December 2017 and 62.4\% in September 2018. The redbelly telapia $C$. zillii was the fourth level with numerical abundance of 180 and a relative abundance of 55.12\% In February 2018 and 23.2\% in May 2018.

Table (4) demonstrated the monthly changes in the numerical and relative abundances of the third station during the collection period. The number of four dominance fish species varied, with $82.24 \%$ of the total number of fish. O. niloticus was the first level, with 442 and $32.57 \%$ for numerical and relative abundances respectively. The relative duration ranged between $11.6 \%$ in September 2018 and $48.96 \%$ in October 2017. C. luteus was second level in number and with 269 and $19.82 \%$ for numerical and relative abundances respectively, ranging from $4.17 \%$ in October 2017 to $55.8 \%$ in February 2018. The Prussian carp C. auratus took the third level with 248 and $18.28 \%$ for numerical and relative abundances respectively, and ranged between 3.03\% in March 2018 and 65.2\% in September 2018. Redbelly tilapia, C. zillii, in the fourth level with 157 and $11.57 \%$ for numerical and relative abundances respectively, and ranged between $3.39 \%$ in July 2018 and $28.35 \%$ in December 2017.

\section{Spatial and temporal Occurrence}

There were 24 species of fishes as appeared in the collection samples. All recorded species were reported in the all stations except $G$. rufa and $P$. bindus, which appeared only at the first station.

Fig. (12) revealed the monthly occurrence of common, seasonal and occasional species in the stations, where eight of common species and two species of seasonal and 14 occasional species. The number of common species in the second station was seven species and three species of seasonal and ten occasional species. The third station presented five common species, three seasonal species and six occasional species.

\section{A-Common species}

It represented with eight species, included three species which appeared in all months (O. niloticus, C. auratus and $P$. abu) and four species (C. zillii, P. latipinna, H. leucisculus and $T$. whiteheadi) were found in ten months, while $O$. aureus was recorded in 11 months. The second station was represented with seven species included three species $(O$. niloticus, $C$. auratus and $O$. aureus) found in 12 months, while the $C$. zillii appeared in 11 months and $C$. luteus in 10 months and $H$. leucisculus and T. whiteheadi appeared in nine months. The third station included five species (O. niloticus, C. auratus, O. aureus, C. luteus) in 12 months and $C$. zillii appeared in ten months.

\section{B-Seasonal species}

It included two species in the first station, the one that appeared in seven months was $P$. subviridis and $B$. fuscus appeared in six months. The number of seasonal species in the second station was three species that appeared in eight months ( $P$. abu, A. sellal 


\section{Hasan \& Resen / Basrah J. Agric. Sci., 32 (Special Issue): 98-123, 2019}

Table (4): The monthly changes in the numerical and relative abundance of the third station during the study.

\begin{tabular}{|c|c|c|c|c|c|c|c|c|c|c|c|c|c|c|c|c|c|c|c|c|c|c|c|c|c|c|}
\hline \multirow{2}{*}{ Species } & $0 \mathrm{ct}-17$ & & $\mathrm{NOV}$ & & Dec & & jan & & Feb & & Mar & & Apr & & May & & Jun & & Jul & & Aug & & Sep & & Total & \multirow{2}{*}{$\%$} \\
\hline & Num & $\%$ & Num & $\%$ & Num & 90 & Num & $\%$ & Num & $\%$ & Num & 90 & Num & $\%$ & Num & $\%$ & Num & $\%$ & Num & $\%$ & Num & $\%$ & Num & 90 & Num & \\
\hline 0. niloticus & 47 & 48.96 & 91 & 37.92 & 30 & 27.78 & 37 & 29.13 & 30 & 21.74 & 35 & 26.52 & 23 & 26.14 & 75 & 51.4 & 34 & 40.48 & 18 & 30.51 & 14 & 20 & 8 & 11.6 & 442 & 32.57 \\
\hline C. luteus & 4 & 4.17 & 20 & 8.33 & 18 & 16.67 & 24 & 18.9 & 77 & 55.8 & 44 & 33.33 & 22 & 25 & 25 & 17.1 & 20 & 23.81 & 8 & 13.56 & 3 & 4.29 & 4 & 5.8 & 269 & 19.82 \\
\hline C. auratus & 10 & 10.42 & 55 & 22.92 & 18 & 16.67 & 6 & 4.72 & 13 & 9.42 & 4 & 3.03 & 6 & 6.82 & 16 & 11 & 11 & 13.1 & 23 & 38.98 & 41 & 58.57 & 45 & 65.2 & 248 & 18.28 \\
\hline C. zillii & 6 & 6.25 & 13 & 5.42 & 19 & 17.59 & 36 & 28.35 & 12 & 8.7 & 32 & 24.24 & 16 & 18.18 & 14 & 9.6 & 7 & 8.33 & 2 & 3.39 & $\cdot$ & $\cdot$ & $\cdot$ & $\cdot$ & 157 & 11.57 \\
\hline 0 . aureus & 18 & 18.75 & 36 & 15 & 13 & 12.04 & 13 & 10.24 & 5 & 3.62 & 14 & 10.61 & 16 & 18.18 & 5 & 3.4 & 7 & 8.33 & 3 & 5.08 & 2 & 2.86 & 4 & 5.8 & 136 & 10.02 \\
\hline P. $a b u$ & 7 & 7.29 & 19 & 7.92 & 6 & 5.56 & 5 & 3.94 & - & $\cdot$ & $\cdot$ & - & 3 & 3.41 & 2 & 1.4 & $\cdot$ & $\cdot$ & $\cdot$ & - & 6 & 8.57 & 4 & 5.8 & 52 & 3.83 \\
\hline L. vorax & 2 & 2.08 & 4 & 1.67 & $\cdot$ & $\cdot$ & - & $\cdot$ & $\cdot$ & $\cdot$ & $\cdot$ & $\cdot$ & $\cdot$ & $\cdot$ & 7 & 4.8 & 2 & 2.38 & 2 & 3.39 & 3 & 4.29 & 1 & 1.4 & 21 & 1.55 \\
\hline A. sellal & 1 & 1.04 & 2 & 0.83 & 1 & 0.93 & 3 & 2.36 & - & $\cdot$ & 3 & 2.27 & - & $\cdot$ & $\cdot$ & - & $\cdot$ & $\cdot$ & - & - & $\cdot$ & - & 1 & 1.4 & 11 & 0.81 \\
\hline H. leucisculus & $\cdot$ & $\cdot$ & $\cdot$ & $\cdot$ & - & $\cdot$ & 3 & 2.36 & - & - & - & - & 2 & 2.27 & - & - & 2 & 2.38 & 2 & 3.39 & $\cdot$ & - & $\cdot$ & $\cdot$ & 9 & 0.66 \\
\hline M. mastacembelus & $\cdot$ & $\cdot$ & $\cdot$ & $\cdot$ & 3 & 2.78 & - & $\cdot$ & 1 & 0.72 & - & $\cdot$ & - & $\cdot$ & - & - & - & $\cdot$ & $\cdot$ & $\cdot$ & $\cdot$ & - & $\cdot$ & - & 4 & 0.29 \\
\hline C. capio & - & $\cdot$ & $\cdot$ & $\cdot$ & $\cdot$ & $\cdot$ & - & - & - & $\cdot$ & $\cdot$ & - & - & - & - & - & - & - & - & - & 1 & 1.43 & 2 & 2.9 & 3 & 0.22 \\
\hline I. whiteheadi & 1 & 1.04 & $\cdot$ & $\cdot$ & $\cdot$ & $\cdot$ & $\cdot$ & - & - & - & - & - & - & $\cdot$ & 1 & 0.7 & $\cdot$ & $\cdot$ & 1 & 1.69 & $\cdot$ & $\cdot$ & $\cdot$ & $\cdot$ & 3 & 0.22 \\
\hline A. urabicus & - & $\cdot$ & $\cdot$ & $\cdot$ & $\cdot$ & $\cdot$ & $\cdot$ & - & - & - & $\cdot$ & - & - & - & $\cdot$ & $\cdot$ & 1 & 1.19 & $\cdot$ & - & $\cdot$ & $\cdot$ & $\cdot$ & $\cdot$ & 1 & 0.07 \\
\hline B. fuscus & $\cdot$ & $\cdot$ & $\cdot$ & $\cdot$ & $\cdot$ & $\cdot$ & $\cdot$ & - & - & - & $\cdot$ & - & - & - & 1 & 0.7 & $\cdot$ & $\cdot$ & $\cdot$ & - & $\cdot$ & - & $\cdot$ & - & 1 & 0.07 \\
\hline Number indiriduals & 96 & $\cdot$ & 240 & $\cdot$ & 108 & - & 127 & . & 138 & - & 132 & . & 88 & . & 146 & $\cdot$ & 84 & - & 59 & - & 70 & . & 69 & . & 1357 & $\cdot$ \\
\hline Number species & 9 & - & 8 & - & 8 & . & 8 & - & 6 & - & 6 & $\cdot$ & 7 & - & 9 & - & 8 & $\cdot$ & 8 & $\cdot$ & 7 & $\cdot$ & 8 & $\cdot$ & $\cdot$ & $\cdot$ \\
\hline
\end{tabular}




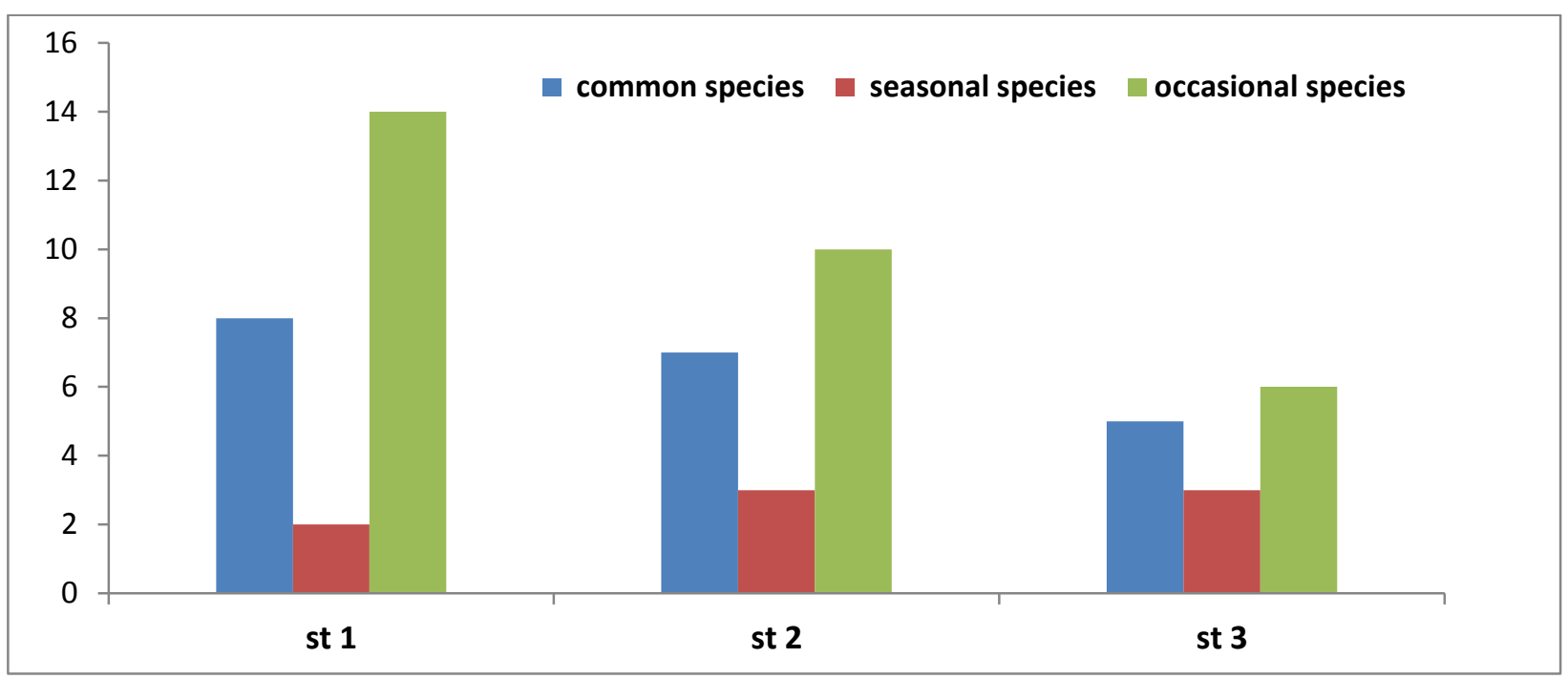

Fig. (12): Monthly changes in the common seasonal and occasional species during the period from Oct 2017 to Nov. 2018.

and T. hamiltonii). The third station included three fish species: $P$. abu appeared in eight months, $L$. vorax appeared in seven months and $A$. sellal appeared in six months.

\section{c-occasional species}

A total of 14 fish species were found in the first station, three species (A. sellal, A. marmid and $T$. hamiltonii) appeared in four months and four species (A. arabicus, $L$. vorax, T. ilisha, S. triostegus) appeared in three months and three species (M. pelusius, $C$. carpio and $B$. dussumieri) appeared in two months and four species (C. luteus, G. rufa, P. bindus and M. mastacembelus) appeared in one month only. The second station represented with ten species included two species (L. vorax and T. ilisha) appeared in four months and two species (S. triostegus and $B$. dussumieri) in the three months and five species (C. carpio, A. arabicus, $M$. pelusius, $P$. subviridis and $P$. latipinna) appeared in two months and one species (M. mastacembelus) appeared in one month. The third station contained six occasional species. One species (H. leucisculus) appeared in four months, one species (T. whiteheadi) appeared in three months, $C$. carpio and $M$. mastacembelus appeared in two months and
B. fuscus and A. arabicus appeared in one month.

\section{Ecological indices}

\section{Diversity index (H)}

Fig. (13) demonstrated the monthly changes in the diversity index values for fish species in the studied stations. The lowest values of $1.13,1.06$ and 1.13 were recorded in September for first, second and third stations respectively, and the highest values of 1.87 and 1.79 in October for first and second stations and 1.67 In December for the third station.

\section{Evenness index $(\mathbf{j})$}

Fig. (14) exhibited the monthly changes in the values of the Evenness index for fish in the stations. The lowest values were 0.44 and 0.54 in September for the first and third stations respectively, 0.42 in the second station and higher values were 0.78 in October for the first station, 0.79 in November for the second station and 0.83 for the third station in March and April.

\section{Richness index (D)}

Fig. (15) displayed the monthly changes in the Richness index values at the study 


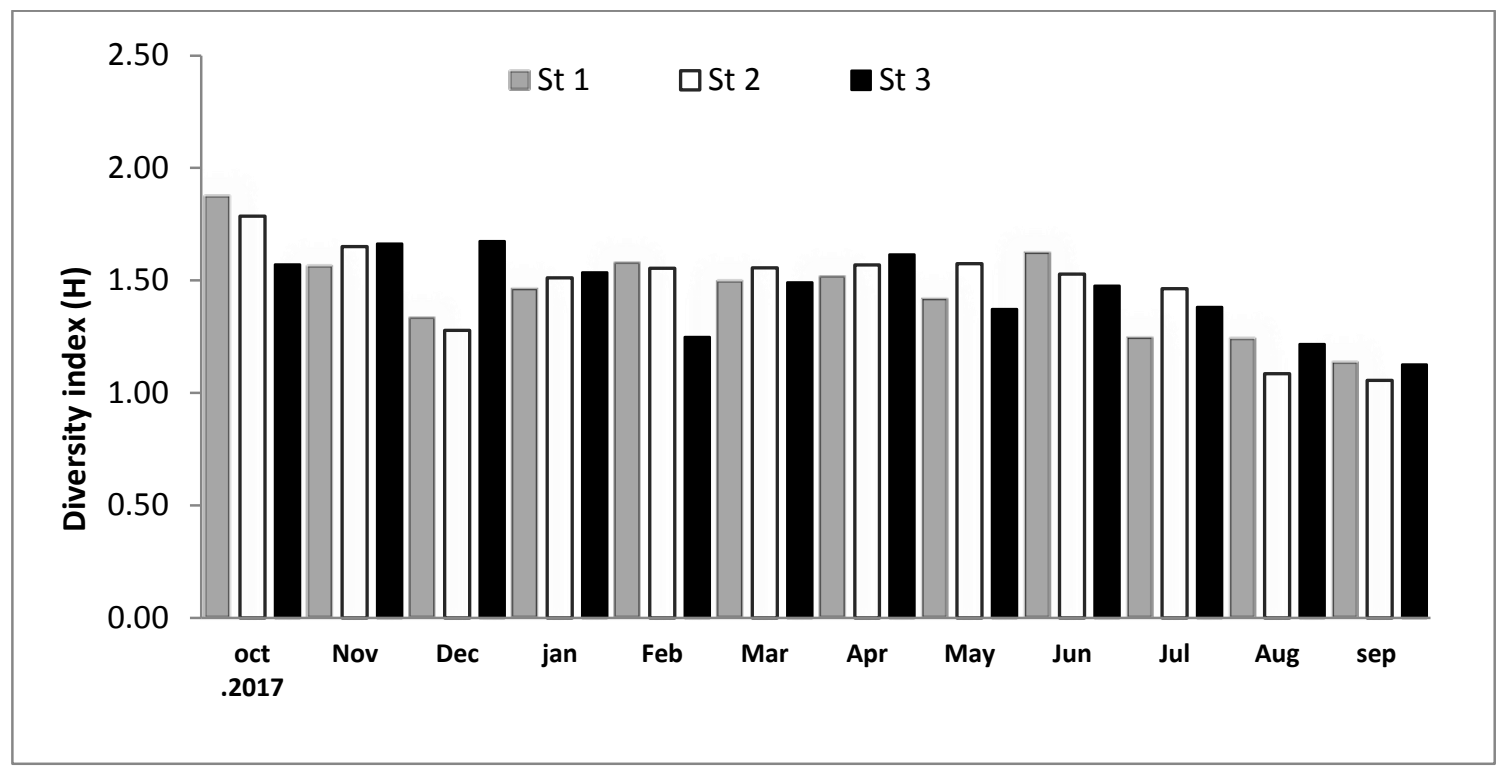

Fig. (13) Monthly changes in the diversity index values of three stations during the period from Oct 2017 to Nov. 2018.

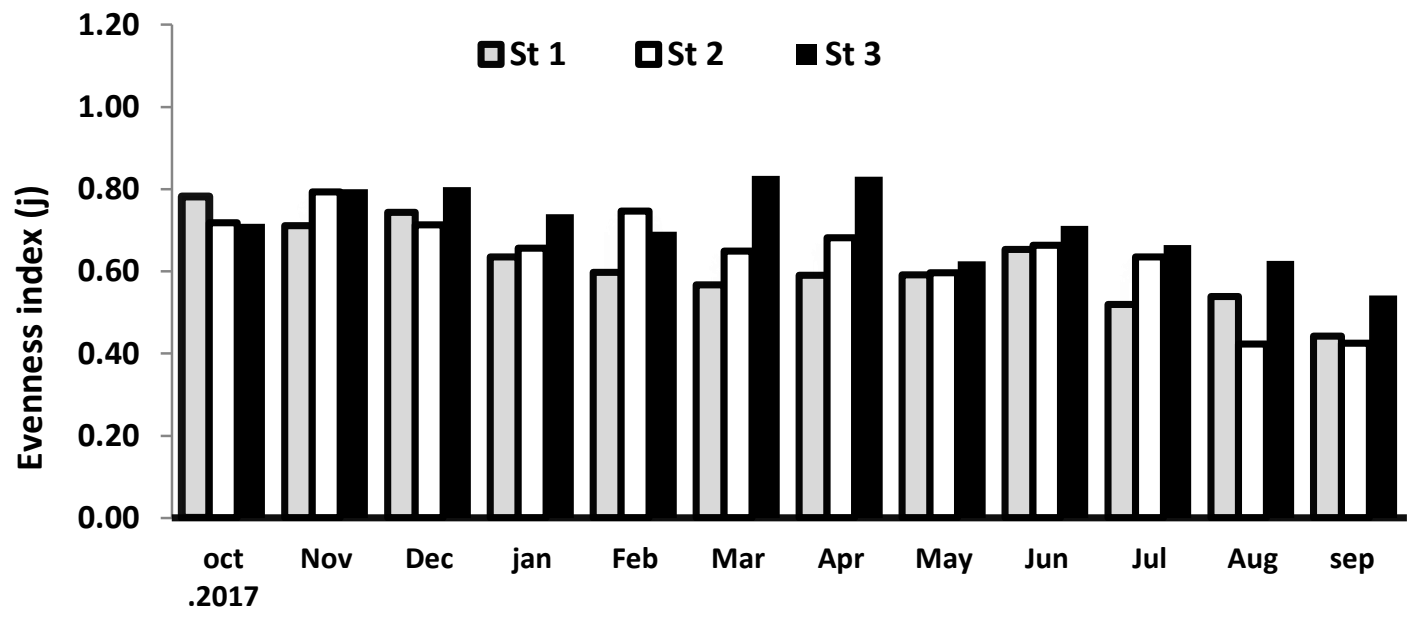

Fig. (14) Monthly changes in the values of the Evenness index of the three stations the ktiban creek during the period from Oct 2017 to Nov. 2018.

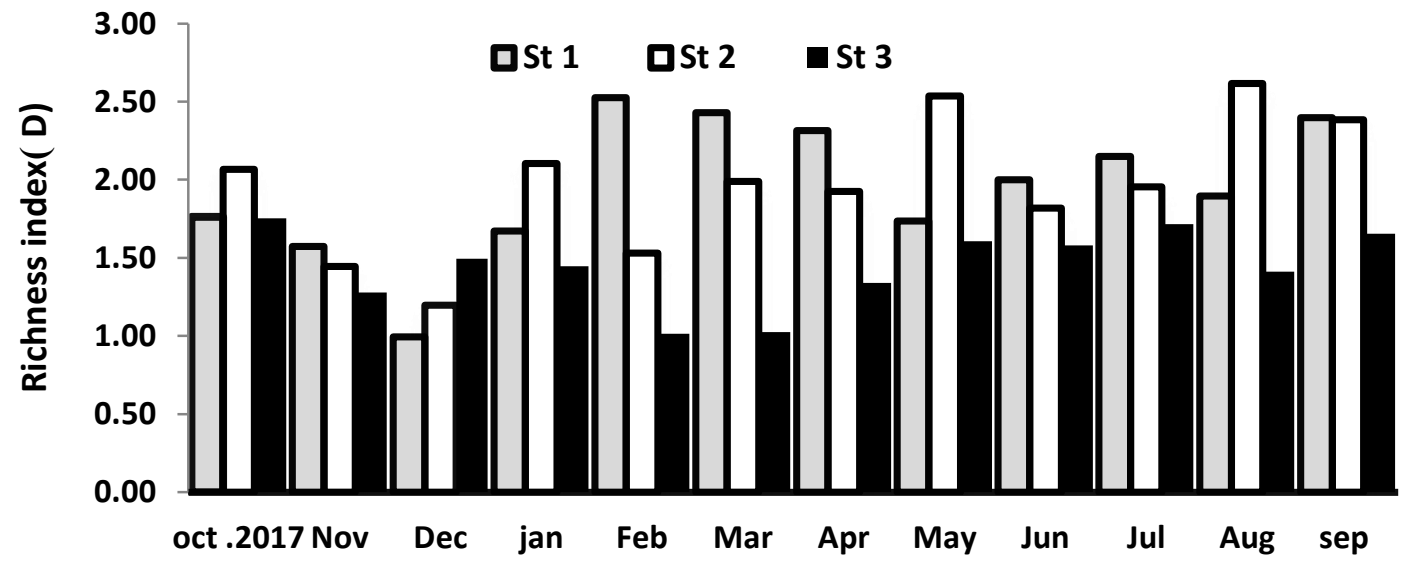

Fig. (15): Monthly changes in the Richness index values in the three stations $n$ ktiban creek during the period from Oct 2017 to Nov. 2018. 
stations. The lowest values of 1.00 and 1.20 were recorded in December for the first and second stations respectively, 1.01 in February for the third station and the highest of 2.53 in February for the first station, 2.62 for the second station and 1.75 In October for the third station.

\section{Discussion}

Environmental factors have interferences influences on aquatic organisms. The effect of one factor on the other cannot be separated. The temperature of the environmental characteristics have effectiveness on the ecosystem, the physiology, behavior of the organisms and the composition of the fish community (Durance \& Ormerod, 2007). Due to local variation, differences in collecting times and water depth variation, as well as thermal capacity of water leading to daily fluctuation and low temperature values (Lampert et al., 1997).

The results of the present study were consistent with other studies (Al-Saad et al., 2015; Mohamed et al., 2017b; Aboud, 2018); Salinity values varied during the study period in the Shatt al-Arab and the ktiban creek, it recorded an increase in August and decreased in January 2018. Salinity levels were higher than in previous years. Salinity values ranged from 1.33 to 2.35 PSU during the period 2003-2004 (Younis et al., 2010), while in the current study, salinity was 1.3 - 8.7 PSU. The reason for those differences to low water discharges from the Tigris and Euphrates rivers to the Shatt al-Arab and the diversion of the river. The fluxes of Karun water from Iranian territory helped to push the saline water from the Arabian Gulf toward Shatt AlArab (Tawash et al., 2013; Hameed \& Aljorany, 2011; Abdullah et al. 2016a).

The study showed a significant increase in the dissolved oxygen values, especially in
December 2017 and January 2018 in the all stations. This is due to low temperatures and continuous mixing of water and the capacity of the surface area (Hassan, 2004).

The transparency of light which is one of the physical characteristics has a direct impact on the presence and spread of fish species (Hussein et al., 2000). It is an important factor for water bodies and an indicator of the relationships between organisms, especially fishes (Mrosso et al., 2004). Due to low water levels and increased concentration of suspended materials that resulted from high productivity which reduces light penetration (Al-Ridini, 2010). The light transparency value was higher in the third station because of low current speed, which leads to the deposition of suspended materials. This study agreed with Abdallah (2015) who also, pointed out that nutrients are a key element in sustaining the primary productivity that forms the basis of food pyramid in the aquatic environment, especially fishes. The results of the present study indicated a clear raise in the values of active nitrates from October 2017 to January 2018 for all stations and this may be due to precipitation on Nitrogenous agricultural land, which eventually drifts into the surrounding water bodies (Hussein \& Fahad, 2008) and does not reduce nitrate to nitrite at low temperatures and thereby increase its concentration (Abdullah et al., 2001), and in decline in June and September in all stations; This may be due to the high concentration of oxygen that oxidizes nitrite to nitrate that resulted the abundance of oxygen at low temperatures and its consumption by phytoplankton and aquatic plants in hot months, reduces the concentration (Abbadi, 2009).

Phosphate values were high in the present study in November 2017, due to their low consumption of phytoplankton and other 
organisms. Rain may play an important role in the decomposition of phosphorus compounds from the earth's crust and the washing of agricultural land and its removal to the water surface (Wetzel, 2001; Sharpley, 2001), and decreased during the rest of the year in all plants, which likely be consumed by phytoplankton, algae and aquatic plants of aquatic organisms, including fishes. This is consistent with Moel (2010), Al-Mayah \& AlAsadi (2010) and Abdullah (2015).

\section{The structure of the fish community}

Table (5) showed a comparison between the structure of the fish community in the Shatt Al-Arab and the ktiban creek in the current study with previous studies. The total number of species was 24 species, while Hussain et al. (1997) recorded 21 species in the Jabassi region, while Younis et al. (2010) recorded 28 species in Qarmat Ali, and Mohamed et al. (2012b; 2013) recorded 18 and 26 species respectively, while Abdullah (2015), Hamid (2017) and Abood (2018) recorded 32, 34 and 45 species respectively.

There are differences in, native marine and exotic fish community compared to previous studies in the Shatt Al-Arab river. The number of native, exotic and marine species in the present study were nine, eight and seven, respectively, while Mohamed et al. (2008) recorded 23 species from the Tigris river North Qurna, eight marine species, the hydrological changes and variation in the amount of river flow have a role in the differences in the structure of the fish community (Larned et al., 2010; Mohamed et al. (2012b; Matono et al., 2014; Whiterod et al., 2015).

Salinity is one of the main factors affecting the composition, distribution and abundance of different species of fishes along the Shatt al-Arab river. The occurrence of any disturbance in the nature of the aquatic body leads to a decline in endemic species with the increase of exotic species (Kumar \& Pandey, 2013).

The study showed the dominance of four fish species in all stations that comprised $72.8 \%$ of the total number of fishes, included $O$. niloticus with $27.7 \%$ and $C$. auratus with $13.61 \%$, O. aureus with $18.9 \%$ and C. zillii with $12.5 \%$. The alien species that have

Table (5): Showed a comparison between the structure of the fish community in the Shatt AlArab and the ktiban creek in the current study with previous studies.

\begin{tabular}{lcccc}
\hline \multicolumn{1}{c}{ Reference } & species & Native species & Marine species & Exotic species \\
\hline Hussain et al. $(1997)$ & 21 & 13 & 5 & 3 \\
\hline Younis et al. $(2010)$ & 28 & 13 & 10 & 5 \\
\hline Mohamed et al. $(2012 \mathrm{~b})$ & 18 & 6 & 7 & 5 \\
\hline Mohamed et al. $(2013)$ & 26 & 11 & 9 & 6 \\
\hline Abdullah (2015) & 32 & 13 & 18 & 11 \\
\hline Humaid (2017) & 34 & 8 & 19 & 12 \\
\hline Abood (2018) & 45 & 14 & 8 & 7 \\
\hline current study & 24 & 9 & & 8 \\
\hline
\end{tabular}


accidentally entered the common water system with neighboring countries (Mutlak \& Al-Faisal, 2009) that tolerate high salinity, low oxygen concentrations, high reproduction capacity and rapid adaptation to new environments (Ridha, 2006). Prussian carp ranked second, an exotic species, first listed in Coad (1991) that tolerate poor environmental conditions, low oxygen concentration, and a wide range of nutrients.

Present study is consistent with most of the studies being conducted by southern in Iraq (Younis et al., 2008; Mohamed et al., 2013; Abdullah, 2015). Hussein (2000) mentioned in his study on five species of fishes introduced into the Shatt al-Arab river, and showed that these species have different capacities to expand their distribution, affecting the composition of the fish community through competition, fertilization, and nesting, are considered one of the reasons for the low densities of local species. $P$. latipinna represent $11.23 \%$ in the first station in the Shatt Al-Arab river between the species caught, that it has invaded this species in Shatt Al-Arab a few years ago, and adapted to the prevailing environmental conditions and spread quickly, one of the advantage of this species that has the ability to live in a wide range of salinity and rivers and lakes with poor water quality (Haney \& Walsh, 2003; Vasagam et al., 2005). There has a sharp decline in the number of common carp in all the stations that have been prevalent in the past two decades and which have been recorded in previous studies more abundantly. This may be attributed to the lack of water levels due to the establishment of several dams on the Tigris and Euphrates in Turkey (Partow, 2001). The absence of some local species such as Mesopotamichthys sharpeyi and Arabibarbus gyrypus were observed by Younis (2005). C. luteus ranked second in the third station with $19.82 \%$, which is due to the fact that it is considered omnivorous habit and has a high potential for competition (Hussain et al., 2008).

Table (6) explained a comparison of the number of common, seasonal and occasional species in the Shatt al-Arab river. The table explained that the highest number of occasional and common species while the lowest number in the seasonal species is consistent with the study of Yunus et al. (2010), Hamid (2017) and Abdullah (2015). This is due to environmental changes affecting the composition of fish populations and the times of duration or the presence of the species (Tyler, 1971).

\section{Ecological indices}

The evidence of biodiversity is great importance in the knowledge of fish community, and the values of biodiversity

Table (6): showed the common, Seasonal and occasional species in the study stations compared to previous studies.

\begin{tabular}{lcccc}
\hline \multicolumn{1}{c}{ Reference } & Duration & Common species & Seasonal species & Occasional species \\
\hline Younis et al. (2010) & $2004-2003$ & 11 & 3 & 14 \\
\hline Mohamed et al.(2013) & $2008-2007$ & 10 & 7 & 9 \\
\hline Abbas (2014) & $2013-2012$ & 5 & 2 & 14 \\
\hline Abdullah (2015) & $2015-2013$ & 15 & 4 & 17 \\
\hline Humaid (2017) & $2016-2015$ & 14 & 3 & 15 \\
\hline Ahmed (2017) & $2017-2016$ & 2 & 6 & 14 \\
\hline current study & $2018-2017$ & 8 & 2 & \\
\hline
\end{tabular}


indices in the knowledge of the number of naturally growing species can that be observed in different locations of the river and also indicate the degree of stability of fish community at very high rates (Sandu \& Oprea, 2013).

The values of the diversity index exhibited the poor range in all stations ranged between 1.06 - 1.87 and the study agreed with Abdullah (2015) and Mohamed et al. (2012a). The study differed from that of Abood (2018) through the study of fish populations in the Shatt al-Arab river due to fishing pressure and the use of illegal tools. The values of the diversity indices are also affected by several environmental factors, including migration, fishing time, competition for food and environmental space (Horn \& Allen, 1985). The values of the Richness index in the study stations ranged from 1.00 to 2.62 and were considered distributed range according to Hussain's study (2014).

The study agreed with Hamid (2017) and Abdullah (2015) and differed with that of Abood (2018). The index of diversity and richness are influenced by the abundance of species in the aquatic environment due to the abundance of marine and exotic species and their high catch ratios (Mohamed et al., 2017b).

Table (7): Comparison of diversity indexes in the three stations in Ktiban creek with previous studies.

\begin{tabular}{ccccc}
\hline & \multicolumn{3}{c}{ indexes } & \\
\cline { 2 - 4 } Reference & $\begin{array}{c}\text { Richness } \\
(\mathbf{D})\end{array}$ & $\begin{array}{c}\text { Evenness } \\
(\mathbf{J})\end{array}$ & $\begin{array}{c}\text { Diversity } \\
(\mathbf{H})\end{array}$ & Study site \\
\hline Hussian et al .(1995) & 2.50 & 0.37 & 1.19 & Shatt Al Arab \\
\hline Hussian et al .(1997) & $0.75-0.10$ & - & $1.75-0.30$ & Shatt Al Arab \\
\hline Younis (2010) & - & $0.60-0.05$ & $1.50-0.42$ & Shatt Al Arab \\
\hline Younis et al. (2010) & $2.18-0.94$ & $0.60-0.05$ & $0.150-0.42$ & Qarmat Ali \\
\hline Mohamed et al. (2012a) & $3.94-2.98$ & $0.79-0.66$ & $2.56-1.91$ & Shatt Al Arab \\
\hline Abbas (2014) & $2.08-1.61$ & $0.91-0.71$ & $1.85-1.26$ & Shatt Al Arab \\
\hline Abdullah (2015) & $2.97-0.95$ & $0.78-0.38$ & $1.90-0.92$ & The northern part of the \\
& & & Shatt Al-Arab \\
\hline Humaid (2017) & $2.26-1.05$ & $0.63-0.23$ & $1.57-0.47$ & Qarmat Ali \\
\hline Ahmed (2017) & $2.95-0.40$ & $0.98-0.51$ & $2.41-0.67$ & Qarmat Ali \\
\hline Aboud (2018) & $3.9-2.0$ & $0.7-0.2$ & $2.2-1.6$ & Al dyeer \\
\hline Current study & $2.62-1.00$ & $0.83-0.44$ & $1.87-1.06$ & Shatt Al Arab \\
\hline
\end{tabular}


The decrease of the freshwater discharge in the Shatt al-Arab was also reflected on the values of the richness index. Warm months represent the preferred seasons for the presence of fishes. This is expressed in many previous studies (olden et al., 2007). The values of the Evenness index were distributed between the scales the half the range, between 0.44 and 0.83 . The values of the Evenness index are influenced by the values of the diversity index, where there is a direct correlation between them. The values of what are limited between (0-1) and the values are closer to 1 , this indicates a lack of the dominance to a certain species (Routledge, 1983), where in the current study values were closer to 1 .

The results of the study agreed with Abdullah, (2015) and converged with Abboud (2018) and Mohamed et al. (2015); This may be due to the increasing the enter the marine species that increase the values of environmental indexes (Hussain et al., 2012). Studies also showed that the greatest proportion of the numerical abundance of fish species is due to the wide range of Evenness index (Hussain et al., 1997; Younis, 2005).

\section{Conclusions}

1-Salinity values in current study were higher than that in historical studies, which effect on the fish assemblage in the area and, and it was positive relation between the salinity and the number of marine fishes.

2-The temperature, salinity and transparency consider the most affect factors on the abundance of fishes.

3- A total of 24 fish species belong to 21 genera and 12 families, with dominance of Cyprinidae (eight species) in the north part of Shatt Al-Arab and Ktiban rivers were reported.
4- The study revealed a decline in relative abundance of common carp, and absence of Mesopotamichthys sharpeyi, Luciobarbus xanthopterus and Arabibarbus grypus.

5-The results were confirming distinct dominance of number of exotic species in compared with other native species.

6- High similarity in fish assemblage between second and third stations and may be related to the sources of the water used Jaccard index to calculated similarity or dissimilarity among stations.

\section{Acknowledgments}

We thanks to Dr. Atheer H. Ali from Department of Fisheries and Marine Resources for confirming identification of the fishes, Dr. Mujtaba A.T. Al-Ankush for analysis of the data by CANOCO software. Prof. Dr. Adil Y. Al-Dubakel from Aquaculture unit for statistical analysis.

Conflict of interest: The authors declare that they have no conflict of interest.

Ethical approval: all applicable national and international guidelines for the care and use of animals were followed.

\section{References}

Abadi, D.A.H. (2009). Study of the quality, quantity and environment of aquatic plants in the southern Iraq marshes during 2006 and 2007. Ph. D Thesis, Coll. Sci., Univ. Basrah: 202pp. (in Arabic).

Abbas, R.H. (2014). Environmental Assessment of Shatt al-Arab in Al-Shafi area. M. Sc. Thesis, Coll. Agric, Univ. Basrah: 71pp. (in Arabic).

Abdullah, A.D.; Karim, U.F.A.K.; Masih, I.; Popescu, I. \& Zaag, P.V.D. (2016). Anthropogenic and tidal influences on salinity levels of the Shatt al-Arab River, 
Basra, Iraq. Int. J. River Bas. Manage., 14(3): 357-366. (in Arabic).

Abdullah, A.AM.; Al-Issa, S.A.Q. \& Jassim, A.K. (2001) Physical and chemical properties of the water of the northern part of the Shatt al-Arab River. Basrah J. Agric. Sci., 14(3): 123-143. (in Arabic).

Abdullah, A.H.J. (2015). Fish diversity and some characteristics of life in the northern part of Shatt Al-Arab and some of its approaches. Ph.D. Thesis, Coll. Agric., Univ. Basrah: 192pp. (in Arabic).

Abood, A.N. (2018). Studying the structure and distribution of fish populations in the Shatt Al -Arab. Ph. D. Thesis, Coll. Agric., Univ. Basrah: 220pp. (in Arabic).

Ahmed, M.H. (2017). Studying the structure of the small fish community in the nursery areas and the effect of organic pollution in the river Karma Ali. M. Sc. Thesis. Coll. Agric., Univ. Basrah: 85pp. (in Arabic).

Al-Abbawy, D.A.H. \& Al-Mayah, A.A. (2010). Ecological survey of aquatic macrophytes in restored Marshes of Southern Iraq during 2006 and 2007. Marsh Bull., 5: 177-196. (in Arabic).

Al-Mayah, A.R.A.A. \& Al-Asadi, W.T. (2010). Hydrilla verticillata (I.f.) Royle was studied in the marshes of southern Iraq. And spread in the marshes of southern Iraq. Basrah Res. (Sci.), 36(1): 38-51. (in Arabic).

Al-Okailee, M.T.K.; Mutlak, F.M. \& Younis, K.H. (2016). Distribution and abundance of Hilsa, Tenualosa ilisha larvae in the Shatt Al-Arab River and East Al-Hammar Marsh. Mesopot. J. Mar. Sci., 31(1): 7584. (in Arabic).

Al-Ridini, A.J. (2010). Environment and nature of the structure of the fish community in Al-Radwaniyah Lake, west of Baghdad. Agric. J., 15(1): 96-106. (in Arabic).

Al-Saad, H.T.; Alhello, A.A.; Al-Kazaeh, D.K.; Alhello, M.A.; Hassan, W.F. \& Mahdi, S. (2015). Analysis of water quality using physicochemical parameters in the Shatt Al-Arab estuary, Iraq. Int. J. Mar. Sci., 5(49): 1-9. (in Arabic).

Al-Tawash, B; Al-Lafta, S.H., \& Merkel, B. (2013). Preliminary assessment of the Shatt al Arab Riverine environment, Basra Government, Southern Iraq. Research, 3(13) :120-136.

Carpenter, K.E.; Krupp,F; Jones, D.A., \&. Zajonz, U (1997). The Living Marine Resources of Kuwait, Eastern Saudi Arabia, Bahrain, Qatar and the United Arab Univ. J .Nat. Sci. Emirates. FAO species Identification Feld Guide for Fishery Purposes, FAO, Rome: viii + 293 pp. + XVII pls.

Clarke, A. (2003). Costs and consequences of evolutionary temperature adaptation. Trends Ecol. Evol., 18(11): 573-581.

Coad, B.W. (1991). Fishes of the Tigris Euphrates Basin: A critical Syllogeus No .68: 31pp.

Coad, B.W.(2017). Freshwater fishes of Iraq: Check list. www.briancoad.com. downloaded 40 March, 2017.

Durance, I. \& Ormerod, S.J. (2007). Climate change effects on upland stream macroinvertebrates over a 25-year period. Glob. Change Biol., 13: 942- 957.

Fazio, F.; Marafioti, S.; Arfuso, F.; Piccione, G. \& Faggio, C. (2013). Influence of different salinity on haematological and biochemical parameters of the widely 
cultured mullet, Mugil cephalus. Marine and Freshwater Behaviour and Physiology, 46(4), 211-218.

Gomes, M.C.; Serrao, E. \& de Fátima Borges, M. (2001). Spatial patterns of groundfish assemblages on the continental shelf of Portugal. ICES J .Mar. Sci, 58(3): 633647.

Hameed, A. and Al-Jorany, Y. S. (2011). Investigation on nutrient behavior along Shatt Al-Arab river Basrah, Iraq. J. Appl. Sci. Res., 7(8): 1340-1345.

Hameed, E.K. (2017). Studying the structure of fish gathering in the Kermat Ali River, Southern Iraq, M. Sc. Thesis, Coll. Agric., Univ. Basrah. 101pp. (in Arabic).

Haney, D.C. \& Walsh, S.J. (2003). Influence of salinity and temperature on the physiology of Limia melanonotata (Cyprinodontiformes: Poeciliidae): A search for abiotic factors limiting insular distribution in Hispaniola. Caribbean J. Sci., 39: 327-337.

Hassan, F.M. (2004). Limnological features of Diwanyia river, Iraq. J. Um-Salama Sci., 1(1): 119- 124.

Horn, M. H. \& Allen, L.G. (1985). Fish community Ecology in southern California Bays and estuaries In: YanezAroncibia, A. (Ed.). Fish community Ecology in estuaries and costal lagoon towards an ecosystem integration.: $654 \mathrm{pp}$.

Hussain, N.A.; Younis, K.H. and yousif, U.H. (1997). The composition of small fish assemblage in the river Shatt Al-Arab near Basrah, Iraq. Acta Hydrobiol., 39: 29-37.

Hussain, N.A; Ali, A.H. \& Lazem, L.F. (2012). Ecological indices of key biological groups in Southern Iraqi marshland during 2005-2007. Mesopot. J. Mar. Sci., , 27 (2): 112 - 125.

Hussain, N.A. (2014). The Iraqi Marshlands Environment. Dar Al Fikr for Publishing and Distribution, Basrah, Iraq: 432pp. (in Arabic).

Hussein, S.A. \& Fahad, K.K. (2008). Seasonal variations in abiotic ecological conditions in Al - Garaf canal one of the main branches to Tigris River Thi Qar province. $3^{\text {rd }}$ Nat. Conf. Ecol. 7-8, Nov., 2008 (Basrah. J. Sci.).

Hussein, S.A. \& Atte, R.S. (2000). Comparative studies on limnological features of the shatt Al-Arab estuary and Mehejran canal. 11. Monthly variations of nutrients. Basrah. J. Agric. Sci., B(2): 5361.

Ibarra, A.A.; Park, Y.S.; Brosse, S.; Reyjol, Y.; Lim, P. \& Lek, S. (2005). Nested patterns of spatial diversity revealed for fish assemblages in a west European river. Ecol. Freshw. Fish., 14(3): 233242.

Jassim, A.A.W. (2003). Some aspects of the life of the fish in the Basrah Canal and the Shatt al-Arab River. Ph. D. Thesis, Coll. Agric., Univ. Basrah: 72 pp. (in Arabic).

Kumar, J. \& Pandey, A.K. (2013). Present status of ichthyofaunal diversity and impact of exotics in Uttar Pradesh. J. Exp. Zool. India, 16 (2): 429-434.

Lampert, W. \& Sommer, U. (1997). Limnology: The Ecology of Lake and Stream. Oxford Univ. Press. AvenueNew York: 324pp.

Larned, S.T.; Datry, T.; Arscott, D.B. \& Tockner, K. (2010). Emerging concepts 
in temporary-river ecology. Freshw. Biol., 55: 717-738.

Lazem , L.F. (2014). Ecological Evaluation of the Shatt Al-Arab River and fish assemblage by Applying Geographical Information System (GIS). Ph. D. Thesis. Coll. Agric, Univ. Basrah.: 134pp.

Lazem, L.F. (2009). The structural characteristics of the fish community and its association with the environmental factors of the Kerma River on southern Iraq. Master Thesis, Coll. Agric, Univ Basrah: 90 pp. (in Arabic).

Margalefe, R. (1968). Perspectives in ecology. Univ. Chicago. Press Chicago., $111 \mathrm{pp}$.

Matono, P.; Bernardo, J.M.; Costa, A.M. \& Ilhéu, M. (2014). Fish response to anthropogenic pressures in temporary streams: the importance of environmental drivers. River Res. Appl., 30: 1281-1295.

Moel, M.S. (2010). Evaluation of the water quality of the northern part of the Shatt al Arab using the Canadian Water Quality Manual (CCME). M. Sc. Thesis, Coll. Sci., Univ. Basrah: 100pp. (in Arabic).

Mohamed A.R.M.; Hussein, S.A. \& Lazem, L.F. (2010). Ecological traits on fish assemblage in the Garma River using Canoca program. Basrah J. Sci., 28: 92106.

Mohamed A.R.M.; Hussein, S.A. \& Lazem, L.F. (2013). Spatiotemporal variability of fish assemblage in the Shatt Al-Arab River, Iraq. Basrah J Agric. Sci., 26(1): 4359.

Mohamed A.R.M.; Resen, A.K. \& Taher, M.M. (2012). Longitudinal patterns of fish community structure in the Shatt Al-
Arab River, Iraq. Basrah J. Sci., 30(2): 65-86.

Mohamed, A.R.M. \& Hussain, N.A. (2012b). Trophic strains and diet shift of The fish assemblage in the recently restored ALHammar marsh, southern Iraq. J. Univ. Duhok, 15(1): 119-127.

Mohamed, A.R.M.; Al-Noor, S.S. \& Faris, R.A. (2008). The status of artisanal fisheries in the lower reaches of Mesopotamian Rivers, North Basrah, Iraq. Proc. $5^{\text {th }}$ Int. Con. Biol. Sci., 5: 128132.

Mohamed, A.R.M.; Hussein, S.A. \& Lazem, L.F. (2015). Spatiotemporal variability of fish assemblage in the Shatt Al-Arab River, Iraq. J. Coast. Life Med, 3(1): 27 34.

Mohamed, A.R.M.; Younis, K.H. \& Hameed, K.H. (2017). Status of Fish Assemblage Structure in the Garmat Ali River, Iraq. IOSR J. Agric. Sci.,10(2): 17-22.

Mohamed, A.R.M.; Younis, K.H. \& Hameed, E.K. (2017b). Status of Fish Assemblage Structure in the Garmat Ali River, Iraq. IOSR J. Agric. Vet. Sci., 10(2): 17-22.

Mohammed, A. R. M. \& Mutlaq F. M. (2008). Structural, abundance and diversity of small fish community in The estuary of the Shatt al-Arab, northwest of the Arabian Gulf. Coll. Agric., Univ. Basrah, 2(21): 151-170. (in Arabic).

Mohammed, A.R.M.; Hussein, S.A. \& Lazem, L.F. (2013). The temporal and spatial variation of fish gathering in the Shatt Al-Arab, Iraq. Basrah Agric. Sci., 26 (1): 43-59. (in Arabic)

Moyel, M.S. (2014). Assessment of water quality of the Shatt Al-Arab River, using 
multivariate statistical technique. Mesopotamia Environ. J., 1(1), 39-46.

Mrosso, H.D.J.; Msuku, B.S. \& Seehausen, O. (2004). Relationship between water transparency and species richness of surviving Haplochromines in selected habitats Mwanza Gulf-lake Victoria. Tanz. J. Sci., 30(1): 101-108.

Odum, W.A. (1970). Insidious alternation the estuarine environment. Trans. Am. Fish. Soc., 99: 836-847.

Olden, J.D.; Hogan, Z.S. \& Zanden, M.J.V. (2007). Small fish, big fish, red fish, blue fish: size-biased extinction risk of the world's freshwater and marine fishes. Glob. Ecol. Biogeogr.,16(6): 694-701.

O'Neill, B.; De Raedemaecker, F.; McGrath, D. \& Brophy, D. (2011). An experimental investigation of salinity effects on growth, development and condition in the European flounder (Platichthys flesus L.). J. Exp. Mar. Biol. Ecol., 410: 39-44.

Partow, H. (2001). The Mesopotamian marsh lands. Demise of an Ecosystem. Early warning and assessment Technical Report, UNEP/DEWA/ TR.o1-3 Rev.1 Pielou, E.C. (1977). Mathematical ecology. John Wiley, New York: 385pp.

Pérez-Robles, J., Re, A.D.; Giffard-Mena, I. \& Díaz, F. (2012). Interactive effects of salinity on oxygen consumption, ammonium excretion, osmoregulation and $\mathrm{Na}+\mathrm{K}+\mathrm{ATP}$ ase expression in the bullseye puffer (Sphoeroides annulatus, Jenyns 1842). Aquac. Res., 43(9): 1372-1383.

Pihl, L. \& Wennhage, H. (2002). Structure and diversity of fish assemblages on rocky and soft bottom shores on the Swedish west coast. J Fish Biol, 61: 148-166.
Rassin, A.K.; Abdel-Hassan, J.K. \& Hamza, A.R. (2016). Some environmental factors and their impact on the fish community composition in the Shatt al-Arab area Shafi, Basrah. $2^{\text {nd }}$ Int. Sci. Biol. Sci., Women Educ. Coll. Univ. Al-Kufa: 75-66. (in Arabic).

Ridha, M.T. (2006). Tilapia Culture in Kuwait: Constraints and Solutions NAGA, WorldFish Center Quarterly, 29(3-4): 7173.

Routledge, R.D. (1983). Evenness indices: are any admissible. OIKOS, 40(1): 149-151.

Sandu, P.G. \& Oprea, L. (2013). Estimating fish communities structure and diversity from Predeltaic Danube Area. Anim. Sci. Biotechnol., 46(2):227-233.

Shannon, C.E. \& Weaver, W. (1949). The Mathematical Theory of Communication, Univ. Illions. Press Urbane, 117pp.

Tyler, A.V. (1971). Periodic and resident components in communities of Atlantic fishes. J. Fish. Board Can., 28(7): 935-946.

Vasagam, K.P.K.; Rajagopal, S. \& Balasubramanian, T. (2005). Effect of salinity on gestation period, fry production, and growth performance of the sailfin molly (Poecilia latipinna Lesueur) in captivity. J. Aquac., (Bamidgeh). 57: 147-152.

Wetzel, R. G. (2001). Limnology: Lake and River Ecosystems, $3^{\text {rd }}$ ed. Academic Press, AQn Elsevier imprint, Sanfrancisco, New York, London: 432pp.

Whiterod, N.S.; Hammer, M.P. \& Vilizzi, L. (2015). Spatial and temporal variability in fish community structure in Mediterranean climate temporar streams. Fund. Appl. Limnol., 187(2): 135-150.

Younis, K.H. (2005). Evaluation of the life of the Shatt al-Arab Fish / karmat Ali, Basrah. 
Hasan \& Resen / Basrah J. Agric. Sci., 32 (Special Issue): 98-123, 2019

Ph. D Thesis, Coll. Sci. Univ. Basrah: 155pp. (in Arabic).

Younis, K.H.; Hussein, A.N. \& Mohammed, A.R.M. (2010). Environmental assessment of the Shatt Al-Arab fish pond Kermat Ali, Basrah using the IBI. Karbala Univ. J.. $1^{\text {st }}$ Sci. Conf., Karbala Univ.: 22-31. (in Arabic). 